OPEN ACCESS

Edited by:

Guoxun Chen,

The University of Tennessee, Knoxville,

United States

Reviewed by:

Xin Wu,

Chinese Academy of Sciences (CAS),

China

Martina Crispo,

Institut Pasteur de Montevideo,

Uruguay

*Correspondence:

Shengli $\mathrm{Li}$

lisheng0677@163.com

Wei Wang

wei.wang@cau.edu.cn

Specialty section:

This article was submitted to

Nutritional Immunology,

a section of the journal

Frontiers in Immunology

Received: 23 November 2021

Accepted: 29 December 2021

Published: 18 January 2022

Citation:

Zheng Y, Xie T, Li S, Wang W,

Wang $Y$, Cao Z and Yang $H$ (2022)

Effects of Selenium as a

Dietary Source on Performance,

Inflammation, Cell Damage, and

Reproduction of Livestock Induced

by Heat Stress: A Review.

Front. Immunol. 12:820853.

doi: 10.3389/fimmu.2021.820853

\section{Effects of Selenium as a Dietary Source on Performance, Inflammation, Cell Damage, and Reproduction of Livestock Induced by Heat Stress: A Review}

\author{
Yuhui Zheng, Tian Xie, Shengli Li ${ }^{*}$,Wei Wang*, Yajing Wang, Zhijun Cao \\ and Hongjian Yang \\ State Key Laboratory of Animal Nutrition, College of Animal Science and Technology, China Agricultural University, \\ Beijing, China
}

Heat stress as a result of global warming has harmful consequences for livestock and is thus becoming an urgent issue for animal husbandry worldwide. Ruminants, growing pigs, and poultry are very susceptible to heat stress because of their fast growth, rapid metabolism, high production levels, and sensitivity to temperature. Heat stress compromises the efficiency of animal husbandry by affecting performance, gastrointestinal health, reproductive physiology, and causing cell damage. Selenium $(\mathrm{Se})$ is an essential nutritional trace element for livestock production, which acts as a structural component in at least 25 selenoproteins (SELs); it is involved in thyroid hormone synthesis, and plays a key role in the antioxidant defense system. Dietary Se supplementation has been confirmed to support gastrointestinal health, production performance, and reproductive physiology under conditions of heat stress. The underlying mechanisms include the regulation of nutrient digestibility influenced by gastrointestinal microorganisms, antioxidant status, and immunocompetence. Moreover, heat stress damage to the gastrointestinal and mammary barrier is closely related to cell physiological functions, such as the fluidity and stability of cellular membranes, and the inhibition of receptors as well as transmembrane transport protein function. Se also plays an important role in inhibiting cell apoptosis and reducing cell inflammatory response induced by heat stress. This review highlights the progress of research regarding the dietary supplementation of $\mathrm{Se}$ in the mitigation of heat stress, addressing its mechanism and explaining the effect of Se on cell damage caused by heat stress, in order to provide a theoretical reference for the use of Se to mitigate heat stress in livestock.

Keywords: selenium, heat stress, gastrointestinal microbiome, inflammation, immunity, antioxidant capacity 


\section{INTRODUCTION}

Ruminants, pigs, and poultry (hereafter grouped as livestock) are extremely susceptible to high temperatures owing to their fast growth rate, fast metabolism, high yields, and sensitivity to temperature. Heat stress caused by global warming has attracted much attention from researchers owing to its harmful effects on livestock, especially high-yielding animals. Heat stress refers to the physiological conditions when the core body temperature of a specific species exceeds the range stipulated by its normal activities. It is caused by the total heat load (internal production and environment) exceeding the heat dissipation capacity (1). Heat stress affects feed intake, the antioxidant system, mitochondrial function, and heat shock protein expression; it disrupts the body's free radical homeostasis and reorganizes the use of protein, fat, and energy; it subsequently affects animal production, reproduction, and health. The effect of heat stress on livestock and its molecular response are as follows: (I) Inhibition of feed intake: the energy requirements of animals increase under heat stress, but heat stress stimulates the hypothalamus to inhibit feed intake of animals by up-regulating the expression of leptin, adiponectin, and their receptors $(2,3)$. (II) Damage to mitochondria: heat stress can also cause histological and morphological damage of mitochondria (4), induce fat and protein degeneration (5), and activate the apoptosis pathway based on the release of cytochrome $C$ (6), which intensifies heat stress damage to the body. (III) Oxidative stress: the excessive production of free radicals and reactive oxygen species caused by heat stress (7) can damage the body's proteins (8), lipids (9), polysaccharides (10), and deoxyribonucleic acid (DNA) (11), and then induce the body to maintain a concentration of reactive oxygen species (ROS) by mobilizing endogenous antioxidants $(12,13)$ and increasing the activity of antioxidant enzymes (14). (IV) Heat shock protein: the expression of heat shock protein induced by heat stress is a repair mechanism for cells to cope with stress, which can prevent the loss of normal protein function induced by the interaction of denatured protein with neighboring proteins (Figure 1).

Selenium (Se) is an essential nutrient trace element for animal husbandry. It belongs to the same family as oxygen and sulfur and can be combined with a variety of elements to form compounds that are very similar to sulfide. Se exists in nature and organisms in organic and inorganic forms; soil (0.1-0.7 mg/ $\mathrm{kg}$ ), plants $(0.02-0.40 \mathrm{mg} / \mathrm{kg})(15)$, animal food sources $(0.03-$ $0.34 \mathrm{mg} / \mathrm{kg}$ ) (16), water (generally $\leq 10 \mathrm{mg} / \mathrm{L})(17)$, and air (1-10 $\left.\mathrm{ng} / \mathrm{m}^{3}\right)(18,19)$ all contain trace amounts of Se. The main inorganic forms of $\mathrm{Se}$ include selenite $\left(\mathrm{SeO}_{3}{ }^{2-}\right)$, selenate $\left(\mathrm{SeO}_{4}{ }^{2-}\right)$, selenide $\left(\mathrm{Se}^{2-}\right)$, and $\mathrm{Se}(20)$. Organic forms include selenomethionine (SeMet), selenocysteine (SeCys), and hydroxy4-methylselenobutyric acid, a new type of organic Se with higher bioavailability (21) (Figure 2A). Se is mainly absorbed in the duodenum and cecum of livestock, and its absorption efficiency in ruminants is much lower than that of monogastric animals (22). Dietary protein, vitamin E (VE), and vitamin A (VA) can enhance Se absorption, while diets rich in carbohydrates or nitrates, sulfates, calcium, arsenic, vitamin C, mercury, or hydrogen cyanide can affect absorption (23). Se is stored in different organs and tissues in the form of SeMet in animals as follows: liver $30 \%$, muscle $30 \%$, kidney $15 \%$, plasma $10 \%$ and other organs $15 \%$ (24). Se is mainly excreted in urine in monogastric animals, while in ruminants, owing to its low intestinal absorption rate, it is mainly excreted in feces (22). The specific metabolism and excretion pathways of Se in animals are shown in Figures 2B, C $(25,26)$. Studies have confirmed that Se can stimulate the formation of antibodies $(27,28)$, enhance
A
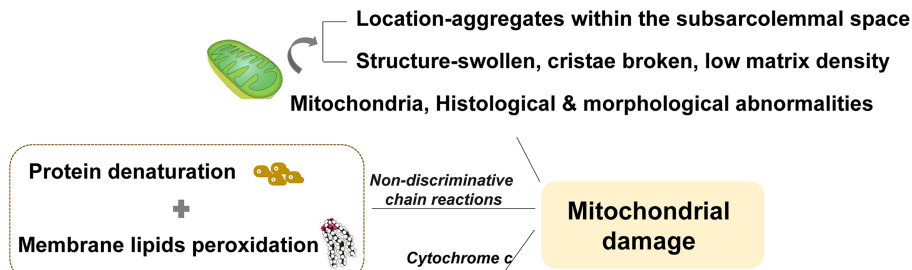

cytochrome

Activates apoptosis proteins-caspases
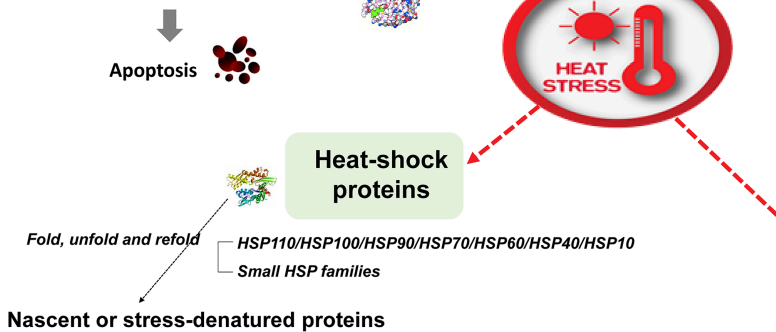

B

Nascent or stress-denatured proteins

Mitochondrial damage
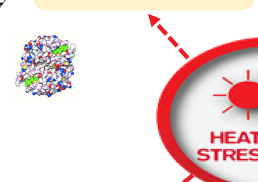

C

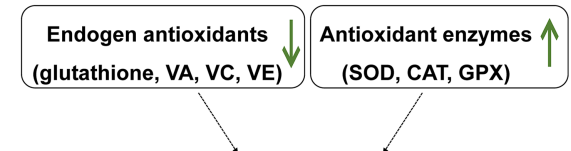

D

Feed intake
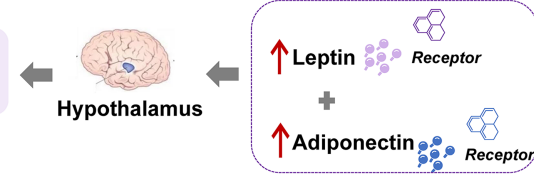

FIGURE 1 | The effect of heat stress on livestock and its molecular response. (A) Mitochondrial damage (B) Heat shock proteins (C) Antioxidant system (D) Feed intake. 


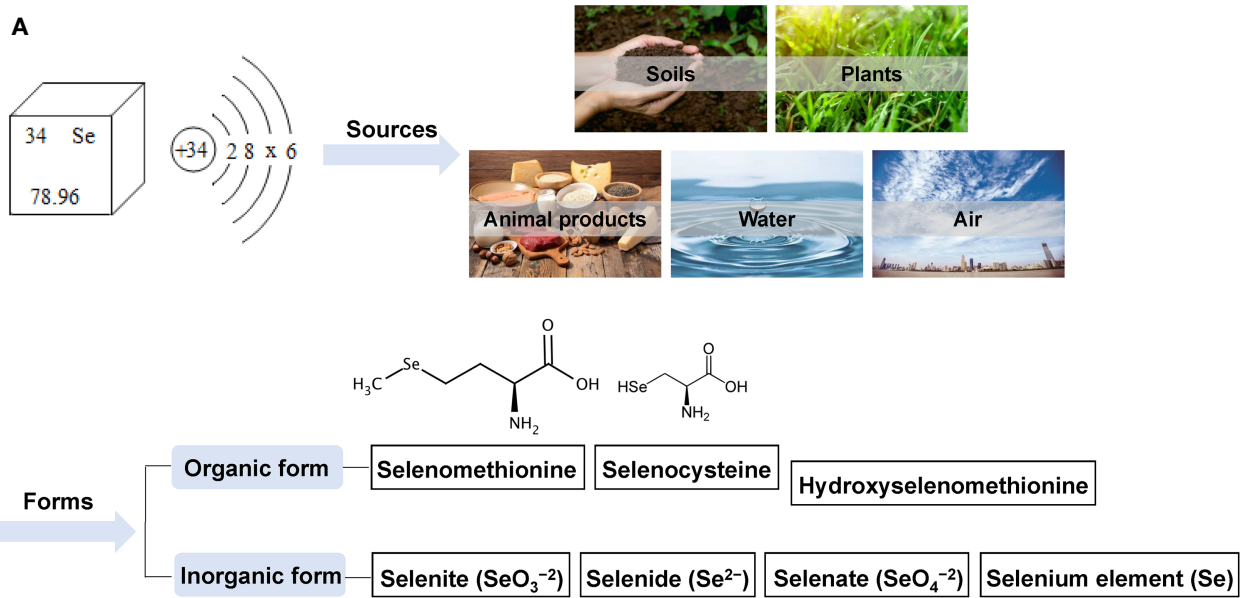

B

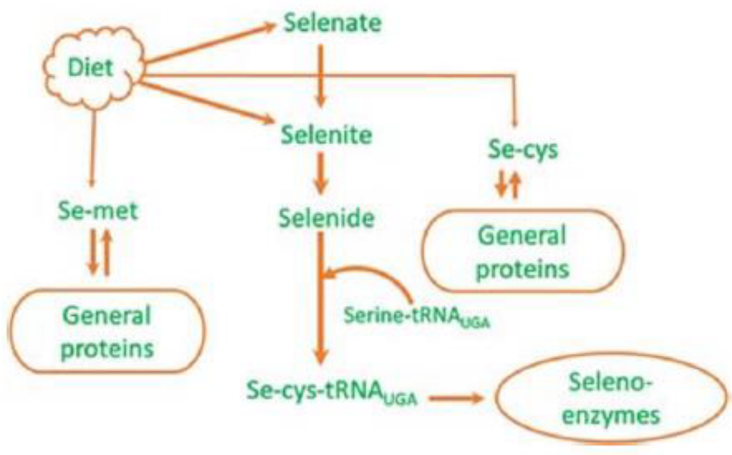

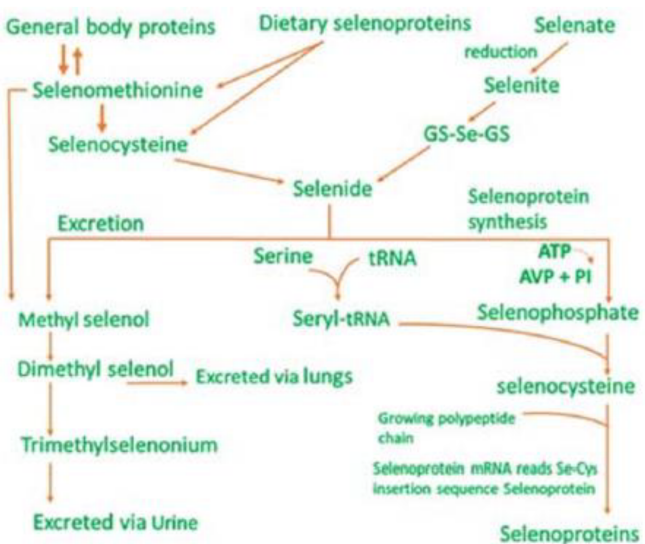

FIGURE 2 | Sources and forms of selenium in nature and its metabolism and excretion in animals. (A) The source and form of selenium in nature (B) Metabolism diagram of selenium in animals (C) Metabolism and excretion of selenium in animals.

the production of neutrophil chemokines (29), prevent cancer $(30,31)$ and cardiovascular diseases $(32,33)$, and enhance animal reproduction (34-36). In addition, the biological functions of Se are mainly mediated by the protein selenoprotein (SEL) containing SeCys, which is the main structural element of SELs such as glutathione peroxidase, thioredoxin reductase, and deiodinase $(37,38)$. Currently, 30 SELs have been identified in 25 mammalian genes, and they all play a key role in biological functions such as antioxidant, thyroid hormone synthesis, reproduction, and DNA synthesis (17).

\section{DIETARY SUPPLEMENTATION OF Se TO IMPROVE THE PERFORMANCE OF LIVESTOCK UNDER HEAT STRESS}

In tropical, subtropical and arid regions, high-temperature environments have become the main environmental factor affecting animal production (26). As the frequency, intensity, and duration of extreme weather events increases, a rising trend of global temperature has been noted. It is estimated that by 2100 , the average global surface temperature will have risen by about $3.7^{\circ} \mathrm{C}(39)$. Heat stress can severely affect the production and quality of meat, eggs, and milk, as well as the metabolism and health of livestock (40-42), and can even lead to fatalities $(14,43)$, causing serious economic loss to the livestock industry. In the USA, for example, the annual economic loss caused by heat stress is as high as US\$1.2 billion (of which, the dairy industry accounts for US\$900 million, and the beef cattle and pigs around US\$300 million) (44).

\section{Growth Performance}

Heat stress has an adverse effect on the food intake, digestion, and growth performance of livestock $(45,46)$. Studies indicate that dietary Se supplementation can significantly reduce the negative impact of heat stress on the growth performance of broilers (47-53). Dietary supplementation of VE and Se can reduce the adverse effects of high ambient temperature on the growth performance of Japanese quail (54), and a combination of $250 \mathrm{mg} \mathrm{VE}$ and $0.2 \mathrm{mg}$ Se can maximize their growth performance (55). Supplementing nano-Se in the diet of 
rabbits suffering severe heat stress can significantly improve their growth performance $(56,57)$, and dietary supplementation of Se and VE can significantly alleviate weight loss in heat-stressed sheep and improve their feed conversion efficiency (58). Such effects are owing to the following factors: (I) Se can improve feed utilization by regulating the metabolism of carbohydrates, lipids, and proteins (59); (II) Se can improve the antioxidant status of animals, reduce oxidative stress induced by heat stress, and reduce the inflammatory response, thereby promoting growth performance; (III) Se can enhance the ability of livestock to regulate their body temperature (for example, dietary Se significantly inhibits rectal temperature increase in sheep (60), lactating cows (61), and growing pigs (62) affected by heat stress; (IV) Se can maintain and improve growth performance by reducing the adverse effects of heat stress on skeletal muscle (63).

\section{Production Performance}

Heat stress leads to energy balance and metabolic disorders, resulting in a decline in the yield and quality of livestock products (64-67). Studies have found that heat stress reduces egg weight, eggshell thickness, egg yolk index, and egg quality $(65,68,69)$. Rozenboim et al. (70) found that supplementing Se to poultry under heat-neutral conditions can increase their egg production and Huff units, and that the supplement SeMet has a stronger protective effect than $\mathrm{Na}_{2} \mathrm{SeO}_{3}$ in reducing oxidative stress caused by heat stress in poultry (71). In addition, dietary Se supplementation could effectively alleviate decreased meat production and the deterioration of meat quality caused by chronic heat stress $(72,73)$. This is because Se can regulate thyroid hormone metabolism, DNA synthesis, cellular antioxidant levels and immune system responses (74-76) reducing the adverse effects of heat stress on the metabolism (77) and meat production of livestock (78-81). Heat stress increases free radical and ROS levels in animals, which induce oxidative stress and metabolic disorders (82), and damage the nutrient content (essential fatty acids) and storage stability (flesh color and lipid oxidation) of meat (83-86). Lipid oxidation leads to the production of volatile secondary lipid oxidation products and lactic acid, and reduces meat quality. Studies indicate that the content of the secondary lipid oxidation product malondialdehyde in heat-stressed broiler breast meat can be increased more than two-fold $(45,84)$. However, the addition of dietary Se can enhance the oxidative stability of lipids in thigh and breast meat, and $125 \mathrm{mg} / \mathrm{kg} \mathrm{VE}$ and $0.5 \mathrm{mg} / \mathrm{kg}$ Se combined supplement is the most effective lipid oxidation inhibitor (78).

Dietary supplementation of Se to heat-stressed sheep can also increase productivity by reducing lipid oxidation in their meat (87). Dietary Se can effectively alleviate the lipid oxidation induced by heat stress, which may be related to an increase in muscle Se content (88-90). Studies have confirmed that the iron, zinc, and Se content of meat is highly correlated with its oxidizing ability (91), and Se is known to be important for improving poultry health and meat quality. Heat stress increases the excretion of minerals in broilers $(92,93)$, thereby reducing the content of vitamins (VA and VE) and minerals (e.g., iron, zinc, Se) in their tissues $(78,94)$, resulting in a decrease in oxidative capacity (91). Dietary Se supplementation can be deposited in muscle tissue, which in turn maintains the oxidative stability of its lipids. In addition, Yang et al. (95) reported that the color of meat depends on myoglobin content, which is reduced after oxidation under heat stress. High ambient temperature will reduce red and yellow coloring and increase the pale color of breast meat in chickens (96). The decrease in value caused by such color changes has resulted in more than a onebillion-dollar loss to the USA meat industry annually (97). An Se-rich probiotic diet has been found to increase the redness and yellowness of broiler breast muscles, and reduces the light color caused by heat stress, so it is a beneficial nutritional supplement for improving meat quality in summer (98).

In dairy farming, the temperature and humidity index (THI) has been widely used to measure the heat stress experienced by dairy cows. The following formula is currently proposed by NRC (99) to calculate THI $\left(\mathrm{THI}=\left[1.8 \times \mathrm{T}_{\mathrm{db}}+32\right]-[0.55-\right.$ $0.0055 \times \mathrm{RH}] \times\left[1.8 \times \mathrm{T}_{\mathrm{db}}-26\right]$; where $\mathrm{T}_{\mathrm{db}}=$ dry bulb temperature, ${ }^{\circ} \mathrm{C} ; \mathrm{RH}=$ Relative humidity, \%). Furthermore, it is recognized that when the average daily THI exceeds 68 , heat stress will cause a decrease in milk production in dairy cows (100). Zimbelman et al. (100) found that when THI increased from 60 to 80 , the milk production of dairy cows decreased linearly (for every increase in THI, milk production decreased by $0.13 \mathrm{~kg} / \mathrm{d}$ ); Bohmanova et al. (101) found that when THI was higher than 74 , an increase of $1 \mathrm{THI}$ resulted in a decrease in milk production of $0.3 \mathrm{~kg} / \mathrm{d}$; furthermore, West et al. (102) confirmed that when THI increased from 72.1 to 83.6 , for each THI increase of 1 , milk production decreased by $0.88 \mathrm{~kg} / \mathrm{d}$.

Further studies have confirmed that heat stress lowers milk quality, which is mainly reflected in the reduction of milk protein, milk fat, and lactose content (103, 104). Compared with other seasons, milk protein content in summer can be reduced by $6 \%$ (103); in a different study of heat stress conditions, the protein content of milk was reduced by $4.8 \%$ (105). Compared with spray-cooled cows in the dry period, the milk protein content in the following lactation was significantly lower in heat-stressed cows (106). Moreover, milk fat percentage in summer is low $(104,107,108)$, and heat stress during the dry period also reduced lactose production of cows in the following lactation $(109,110)$. Studies have shown that Se can effectively slow down oxidative stress and inflammation in dairy cows, thereby improving health, reducing morbidity, and promoting milk protein synthesis (111-113). However, whether Se can slow down the effects of heat stress on milk production and milk composition needs to be further studied.

\section{DIETARY SUPPLEMENTATION OF Se TO RELIEVE INFLAMMATION AND ENHANCE IMMUNOCOMPETENCE OF HEAT STRESS LIVESTOCK}

The mammalian immune system defends against environmental challenges. Stressors suppress immune system components, thereby enhancing the susceptibility of animals to diseases and inducing inflammatory reactions (114). The negative impact of 
heat stress on the immune system is mediated by cellular immunity and humoral immunity. Cortisol production during acute stress will stimulate the immune system, and during chronic stress, its secretion is related to immunosuppression $(115,116)$. Se has been shown to be used by almost all tissues and cell types, including those involved in innate and adaptive immune responses (117-119). By increasing Se intake, cellmediated and humoral immune responses are enhanced (120, 121). Relevant studies have confirmed that dietary Se supplementation can slow down the inflammatory response induced by heat stress through regulating the immune response, thereby improving livestock production.

\section{Inflammation Reduction}

Damage to gastrointestinal physiology and barrier function under acute stress and other pathological conditions can induce various diseases. The gastrointestinal mucosa is covered by the lamina propria and a single layer of epithelial cells. These epithelial cells are connected by tight junctions to form a barrier that restricts the free entry and exit of materials from the intestinal lumen (122-124). The lamina propria contains immune cells, including eosinophils, neutrophils, macrophages, lymphocytes, and mast cells, which can protect the intestines from microbes and their toxic products (125). However, when livestock are in a hot environment, blood is redistributed from visceral tissues to peripheral tissues to maximize radiant heat (126), so the gastrointestinal tract may experience fever, hypoxia, and even inflammation (127-129). Heat stress damages intestinal tight junctions, resulting in impaired intestinal barrier integrity and increased epithelial permeability, which in turn leads to the entry of bacterial endotoxins that trigger local inflammation and immune responses (125), and induce intestinal barrier dysfunction (130). Moreover, there is evidence that oxidative stress caused by heat or other factors can lead to the accumulation of ROS and reactive nitrogen species, which are important predisposing factors of gastrointestinal diseases such as inflammatory bowel disease, intestinal fibrosis and ulcers, colitis, and colon cancer $(122,131)$. Study found that organic Se from Se-enriched Agaricus bisporus can increase the expression of glutathione peroxidase (GPx) by restoring epithelial ion transport and barrier functions, thereby protecting the gastrointestinal tract of rats from heat-induced oxidative stress (132). Increased dietary Se and VE alleviates the effect of heat stress on the integrity of the porcine jejunum and ileal barrier (133). Furthermore, Se has a protective effect on barrier damage and inflammation caused by heat stress in the jejunum of growing pigs (134). Therefore, Se can effectively alleviate intestinal barrier damage induced by heat stress, and follow-up studies should continue to focus on its impact on the structure and function of the intestinal tract of livestock.

According to reports, chronic heat stress significantly reduces liver weight and affects the body's oxidation response, immune defense, and metabolism $(64,135,136)$. It is known that longterm acute heat stress can cause chronic liver damage (137). Moreover, exposure of aged rats to acute heat stress $\left(40-42^{\circ} \mathrm{C}\right.$ for 24-48 hours) causes liver damage, increased levels of ROS, and changes intracellular signal transduction (138). Further studies have confirmed that dietary Se supplementation can reduce liver oxidative damage after heat stress in rats. This may be related to the ability of Se to activate liver marker enzymes, liver antioxidant status, and liver stress related genes (for example, antioxidant, inflammation, fibrosis, apoptosis, and heat shock) (139). Heat stress significantly increased the activities of aspartate transaminase, alkaline phosphatase, and lactate dehydrogenase in liver tissues; it also increased the content of malondialdehyde, but significantly reduced the level of serum total protein, superoxide dismutase (SOD), and total resistance. Supplementing with Se-rich probiotics can slow down liver damage induced by heat stress by inhibiting liver oxidation, inflammation, and necrosis in a high temperature environment. Compared with a heat stress group, Se supplementation reduced the expression of liver pro-inflammatory cytokines and nuclear factor kappa-B (NF- $\mathrm{KB})$, and reached levels similar to those of a control group that were not exposed to heat stress (139-142). These findings are consistent with previous reports that Se has anti-inflammatory properties $(142,143)$, and its antiinflammatory function may be owing to (I) the presence of specific SELs reducing oxidation-induced inflammatory changes in the liver, such as GPx (143-147); (II) Se can improve immunity by up-regulating the ability of immune active cells to respond to inflammation (148-150).

Wooden breast is a type of degenerative myopathy seen in modern broilers, which decreases the quality of breast meat. Studies have confirmed that dietary supplementation of organic Se can improve broiler meat production and increase carcass integrity, thus reducing the incidence of wooden breast. This effect is most likely to be achieved by simultaneously improving the exogenous and endogenous antioxidant status, reducing oxidative stress, and improving tissue healing processes (151). Moreover, heat stress can induce inflammatory damage to mouse lungs, leading to pulmonary edema and lymphocyte infiltration. Lastly, under heat stress conditions and a low-Se diet, the poultry lung exudes large numbers of inflammatory cells $(152,153)$, which may indicate that the addition of Se in the diet is an important substance to prevent inflammatory damage to lungs.

\section{Immunocompetence Enhancement}

Under heat stress, an animal's continuous panting changes its blood $\mathrm{pH}$ value, leading to respiratory alkalosis. In addition, changes in blood $\mathrm{pH}$ can impair immune function and hormonal activity (154). Heat stress seriously damages the growth performance and immunity of livestock, but dietary Se supplementation has been shown to improve immune response in heat stressed broilers $(63,74)$; Se also supports the immune systems production of inflammation-related enzymes to kill pathogens (155). As mentioned before, heat stress can lead to oxidative stress, including inflammation $(156,157)$, the first line defense in all forms of cell damage, leading to removal of cell damage, and initiation of cell repair. However, when an inflammatory response is excessive, it causes damage to the surrounding normal cells. When an animal is subjected to oxidative stress such as heat stress, it manifests as the 
overexpression of lipopolysaccharide or ROS in the body, which is recognized by Toll-like receptors on the surface of immune

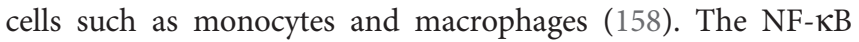
pathway initiates the expression of inflammatory genes and produces interleukin (IL) 1, IL-4, IL-6, tumor necrosis factor- $\alpha$ (TNF- $\alpha)$, and other cytokines, which induce an immune response $(159,160)$. Additionally, heat stress activates the hypothalamic-pituitary-adrenal axis of livestock, which releases glucocorticoids when activated, inhibits the synthesis and release of cytokines, and disrupts the balance between pro-inflammatory and anti-inflammatory factors. The resulting decreased immunity of livestock causes inflammation and reduced feed intake and growth rate, that lead to economic losses in animal husbandry $(114,161)$.

According to report, the source and level of Se have no notable effect on the performance of broilers subjected to heat stress, via spleen and bursal index, blood biochemical indicators, and antibody response to infectious bursal disease virus (162). However, adding SeMet to the diet can improve the feed efficiency of heat-stressed broilers and enhance cell-mediated immunity and humoral immunity (74). Another study showed that Se supplementation had no notable effect on the performance and relative quality of lymphatic organs, but it did improve the antibody response and blood lipid characteristics of heat-stressed broiler red blood cells (163). That is, heat stress significantly reduced the relative quality of the immune organs of broilers and the primary and secondary antibody responses to their red blood cells, while dietary Se supplementation effectively mitigated the negative impact of heat stress on red blood cell secondary antibody responses (163). In addition, studies have found that when sheep are exposed to heat stress, higher dietary Se levels can enhance antibody titers of red blood cells. Supplementation of Se did not affect serum antibody titer of the anti-Newcastle vaccine in broilers (74), and the antibody titer of serum anti-H5N1 increased with the increase of dietary Se level; furthermore, organic Se had a better effect on antibody titer, indicating that Se supplementation using a specific Se source can improve the immune function of heatstressed broilers (164).

Under heat stress conditions, corticosteroids released in the blood reduce the number of lymphocytes (165), and the immune system is stimulated to increase the number of heterophile cells, which are the first line of defense against stress damage (166). Leng et al. (167) found that organic Se supplements can enhance poultry immune system function by improving the ability of immune active cells to resist infection. Studies have found that: under heat stress, as the dietary Se level increases, the number of heterophils, monocytes, and eosinophils gradually decrease, and serum total protein and albumin levels gradually increase (168); a $5 \mathrm{mg}$ Se treatment can reduce the rectal temperature of sheep by $0.3^{\circ} \mathrm{C}$, reduce weight loss by $4.5 \%$, and increase the number of eosinophils (60); injection of antioxidants containing Se, copper, zinc, manganese, VA, VE, etc. before and after weaning of calves in summer can increase their blood immunoglobulin (IgG, IgM, and $\operatorname{IgA}$ ) concentrations and serum total white blood cells (neutrophils and monocytes) (169); dietary Se supplementation can increase the number of hemameba and hemoglobin in poultry blood (170); 0.25 ppm Se can significantly improve the growth performance of broiler chickens, promote their immune response and lymphatic organ development, and can also increase their serum antioxidant activity and the ratio of heterophile cells to lymphocytes, and reduce the gene expression of heat shock protein (HSP) 70 (171). Furthermore, heat stress-induced cell damage is usually accompanied by abnormal expression of SEL coding genes and SELs, and Se supplementation mainly reduces cell damage induced by heat stress via regulating the expression of SELs; that is, Se restores the expression of most SELs in heat-stressed cells at both mRNA and protein levels; in addition, organic Se has a better effect than inorganic Se.

It is known that Se can improve the immune response by changing the production of certain cytokines in immune cells and enhancing the resistance of immune cells to oxidative stress (172). Se added in the diet alone or in combination with vitamins can alleviate the damage caused by oxidative stress and improve immunity (173). Abdel-Moneim et al. (63) supplemented heatstressed broilers with Se and the levels of immunoglobulins in broilers were notably increased. Moreover, the study found that the addition of dietary Se prevented the up-regulation of six inflammation-related genes induced by heat stress (IL-6, IL-8, intercellular cell adhesion molecule-1, interferon- $\beta$, and inducible nitric oxide synthase-2), reduced the expression of pro-inflammatory cytokines in porcine small intestinal epithelial (IPEC-J2) cells under heat stress, and effectively alleviated the adverse effects of acute heat stress on the expression of TNF- $\alpha$ and IFN- $\gamma$, thereby reducing immune dysfunction (174). Compared with inorganic Se, an organic Se group had a lower expression of pro-inflammatory genes and better protection (175). Studies have also found that although dietary Se supplementation can inhibit the expression of TNF- $\alpha$ in heat stressed broilers, it cannot prevent the down-regulation of TNF$\alpha$ expression in IPEC-J2 cells induced by heat stress; therefore, Se can resist heat stress induced inflammatory damage, but this is not achieved by inhibiting the expression of TNF- $\alpha$ (172).

\section{DIETARY SUPPLEMENTATION OF Se TO IMPROVE ANTIOXIDANT STATUS OF HEAT STRESS IN LIVESTOCK}

Oxidative stress is one of the important factors leading to animal inflammation and immune disorder. As an antioxidant, the moderating effect of dietary Se on inflammatory response induced by heat stress is closely related to its ability to improve antioxidant status of animals. An imbalance between the production of oxides in the body and the antioxidant defense system is the root cause of oxidative stress (176). The biochemical and physiological reactions related to heat stress will increase the production of free radicals $(45,46)$. Excess free radicals will interact with protein, carbohydrates, lipids, and cells to destroy their structure and function (177); that is, oxidative 
stress occurs. Free radicals include lipid peroxides, lipid free radicals, ROS, and reactive nitrogen free radicals. Among them, ROS is produced endogenously by organisms during oxidative metabolism. Under normal circumstances, ROS is an important secondary messenger that affects intracellular signal transduction and redox regulation (178), and there is a balance between its production and antioxidant defense. However, under heat stress, the antioxidant defense of cells is unbalanced, and excessive ROS can cause severe damage to biomolecules (lipids, proteins, and nucleic acids), leading to the destruction of cell membrane fluidity and cell apoptosis $(179,180)$. Studies have shown that heat stress prevents the increase in ROS production in IPEC-J2 cells, and the redox balance is disrupted to trigger oxidative stress. Supplementing Se in an organic form can reduce ROS levels and thus alleviate oxidative stress (175).

Se mainly functions passes through Se such as GPx, thioredoxin (Trx), TrxR, and SELP. Proteins exert an antioxidant function, and there are 25 types of SELs with important physiological functions. The increase in antioxidant capacity is attributed to the inducible Se-dependent antioxidant enzymes. Se is a component of glutathione peroxidase, which combines with VE to counteract free radicals (181). VE is the main fat-soluble antioxidant found in cell membranes. It plays an important role as a chain-cut lipid antioxidant and free radical scavenger in the membranes of cells and subcellular organs (182). Recent studies have shown that VE supplementation has a beneficial effect on meat quality (183), and its combined use with Se can more effectively improve the antioxidant defense system of cells and tissues (78). Glutathione peroxidase can remove ROS, protect cells from oxidative stress damage (184, 185), and prevent lipid and protein oxidation. Studies have shown that dietary Se supplementation can increase the serum Se content and the activity of GPx in broilers, calves, lactating dairy cows, and other animals $(63,169,186)$.

At present, the Se sources that researchers add to the diet mainly include SS, SeMet hydroxy analogs, yeast Se, and nanoSe. Different Se sources can increase the activity of GPx in animals under heat stress $(63,186-188)$. In ruminants, the efficiency of rumen microorganisms using organic Se is 3.8 to 4 -fold greater than that of inorganic Se; it is therefore more conducive for rumen microorganisms to synthesize antioxidant enzymes from organic Se in the diet through redox reactions (189). Sun et al. (186) found that the addition of $0.3 \mathrm{mg} / \mathrm{kg} \mathrm{DM}$ Se in the form of organic Se to the diets of Holstein dairy cows in mid-lactation allowed them to remain stable under heat stress, while GPx activity in the serum of the cows in a similar inorganic Se group decreased gradually. Furthermore, $\operatorname{Trx}$ is a multifunctional acidic protein, which exists in two subtypes of Trx 1 and Trx 2 in animals; TrxR is a pyridine nucleotide/disulfide oxidoreductase, including two isoenzymes TrxR1 and TrxR2. Research has found that the content of Trx in the culture of Bovine Mammary Epithelial Cells was significantly lower than that of heat-treated cells after adding $1 \mu \mathrm{M}$ SS (190).

The concentration of oxidative stress biomarkers such as SOD, biological antioxidant potential (BAP), and advanced oxidation protein products (AOPP) can also reflect the degree of cellular damage under heat stress. During heat stress, the accumulation of reactive oxygen metabolite ROM in the body leads to a decrease in plasma BAP. The ratio of the two (ROM : BAP) is defined as the Oxidative Stress Index (OSI). AOPP is a marker of protein oxidation when the body is subjected to heat stress, and it also mediates inflammation. Chauhan et al. (191) fed a diet containing $100 \mathrm{IU}$ VE/kg DM and $1.20 \mathrm{mg} \mathrm{Se} / \mathrm{kg} \mathrm{DM}$ to heat-stressed ewes; the results showed that the serum active oxygen metabolites of the ewes were significantly reduced (114 vs. 85 units/dL; $\mathrm{P}<0.005)$, physiological antioxidant potential increased (3688 vs. $3985 \mu \mathrm{mol} / \mathrm{L} ; \mathrm{P}=0.070)$, heat stress index (ROM/BAP) decreased by $30 \%$, and there was a downward trend of AOPP (19.4 vs. $18.8 \mathrm{~mol} / \mathrm{L}$ ). However, Liu et al. (62) found that feeding $1.0 \mathrm{ppm}$ yeast $\mathrm{Se}$ to sows did not alleviate the decrease in blood BAP affect the increase in AOPP during heat stress, but only increased GPx activity by $13 \%$. The above results suggest that when supplementing Se in livestock diets, we should fully consider whether the background value of Se in the basal diet meets the nutritional needs of experimental animals to determine whether additional Se sources can improve oxidative stress. However, it should be noted that Se and VE have a synergistic effect, therefore supplementing the two together may have a better effect.

Oxidative stress activates the heat shock response (192). Heat shock proteins (HSPs), molecular chaperone proteins expressed by the body under stress, can sense oxidative stress and restore physiological protein conformation during and after such stress. The significant increase in their expression is an adaptive mechanism for cells to respond to oxidative stress. When heat stress occurs, Heat shock transcription factor (HSF) is separated from HSP, and HSF enters the nucleus to induce heat shock elements to regulate gene expression and activate the transcription and translation process of HSP (19). According to molecular weight and amino acid sequence, HSPs can be divided into six families: HSP110, HSP90, HSP70, HSP60, small molecule HSPs (HSP27, HSP33, etc.), and ubiquitin. Most HSPs have molecular chaperone protein activity to prevent misfolded protein aggregation that causes damage to cells and promotes the formation of the correct structure of newly synthesized proteins (193). Supplementing Se can significantly reduce the production of HSPs in cells, alleviate the need of cells for HSP protection under high temperature stress, and alleviate oxidative stress (190).

\section{DIETARY SUPPLEMENTATION OF Se TO INCREASE NUTRIENT DIGESTIBILITY AND REGULATE THE GASTROINTESTINAL MICROBIOME OF HEAT STRESSED LIVESTOCK}

\section{Feed Intake and Nutrient Digestibility}

Loss of livestock performance is mainly owing to energy loss caused by reduced feed intake, consumption of feed of low nutrient content, and temperature regulation. Therefore, 
maintaining the nutrient concentration required for the health and production of heat-stressed livestock is challenging (194). Heat stress adversely affects the feed intake of broilers (195), pigs (196-198), sheep, and dairy cows (191), and the poor health and feed intake associated with heat stress further negatively affects the yield and quality of livestock products. It has been shown that diets supplemented with Se can alleviate the adverse effects of heat stress on animal feed intake and mortality (199).

The effect of heat stress on feed intake $(198,200)$ is related to heat damage to the intestinal epithelial cells $(201,202)$. Thus, the effect of Se on the feed intake of heat-stressed livestock may be closely related to its mitigation of intestinal injury. Studies found that when broilers were exposed to heat stress, the flow of blood and nutrients to their gastrointestinal tract was reduced, which led to intestinal hypoxia, adenosine triphosphate consumption, intracellular acidosis, and oxidative and nitrative stress, resulting in changes in intestinal function and integrity (203). Increased intestinal permeability increases the leakage of lipopolysaccharides to the internal environment, leading to eventual multiple organ failure (203). There are also report indicating that heat stress up-regulates the mRNA and protein expression of HSP70, HSP90, and nuclear factor kappa-B, but reduces epidermal growth factor in the jejunal mucosa of blackbone chickens (204). Damage to the gastrointestinal tract reduces Se absorption, which further leads to Se deficiency. In addition, Se can affect gastrointestinal tissues by regulating the production of inflammatory cytokines and increasing the antioxidant status. Se deficiency can lead to the production of harmful free radicals including oxygen and nitrogen free radicals, and at the same time reduce the antioxidant capacity of the intestinal tract, resulting in oxidative damage to the intestinal tissues of chickens (205). Current research shows that: $1.2 \mathrm{ppm}$ of nano-Se supplements can reduce lipid peroxidation and help broilers maintain intestinal structure under heat stress (206); adding 1-3 ppm sodium selenite (SS) to the diet for 90 days increases the Se concentration and the expression of SEL in the gastrointestinal tract of poultry (207); the addition of $0.4 \mathrm{mg}$ of SS per kilogram of diet can enhance the activity of GPx in the blood and liver of broilers and the activity of thioredoxin in the duodenal mucosa, liver, and kidney (208). Therefore, dietary supplementation of Se can effectively reduce heat stress damage to the gastrointestinal tract of livestock, thereby effectively maintaining feed intake.

The reduction of feed intake under high temperatures is mainly to reduce heat production to adapt to the hot environment (196, 197), and the effect of Se on heat-stressed livestock feed intake may be related to its ability to promote digestion and absorption and improve the digestibility of nutrients. Under heat stress conditions, the reduction of feed intake limits total nutrient intake. Furthermore, in order to prevent heat stroke, livestock must prioritize heat dissipation and survival to combat heat stress over other biological processes such as animal production (67, 209). For example, related studies have shown that accelerated respiration for heat dissipation, increases the synthesis of heat shock proteins to prevent cell damage $(133,210)$, inflammation (211), and the physiological process of repairing damaged tissues (133) - further increasing the mobilization of a sow's body reserves and impairing production performance and energy availability, as well as nutrient supply. Studies have shown that adding Se to the diet can effectively improve the gastrointestinal function of livestock and the apparent digestibility of nutrients: Wei et al. (212) confirmed that dietary supplementation of $0.3 \mathrm{mg} /$ $\mathrm{kg}$ DM Se can promote rumen fermentation and the apparent digestibility of crude protein (CP), neutral detergent fiber (NDF), acid detergent fiber (ADF), and Se in mid-lactation dairy cows; Hassan et al. (57) found that adding $0.5 \mathrm{mg} / \mathrm{kg}$ of Se-enriched spirulina to the diet increased the apparent digestibility of DM, organic matter $(\mathrm{OM}), \mathrm{CP}$, ether extract $(\mathrm{EE})$, and nitrogen free extract in heat-stressed rabbits; Alimohamady et al. (213) showed that dietary Se supplementation increased the digestibility of DM, $\mathrm{OM}, \mathrm{CP}, \mathrm{NDF}$, and ADF in 4 to 5 month old lambs.

Both inorganic Se and organic Se can be added to livestock diets. Inorganic Se is more easily reduced to elemental Se that is difficult for the body to use under acidic conditions; whereas organic Se can directly form microbial protein without being reduced to the intermediate product $\mathrm{H}_{2} \mathrm{Se}$, which improves utilization efficiency (189). The study by Zhang et al. (214) found that coating the Se source is also a way to improve its utilization, and they found that a $0.3 \mathrm{mg} \mathrm{Se} / \mathrm{kg}$ inorganic Se coating treatment significantly increased the apparent digestibility of DM, OM, and $\mathrm{CP}$ in dairy cows. Blood flow plays an important role in controlling body temperature: although under heat stress, blood flow distribution shifts from internal organs to peripheral capillaries to quickly lower body temperature, decreased visceral blood flow can lead to hypoxia in gastrointestinal tissues. When the body lacks an adequate supply of oxygen (such as during metabolism), oxidative stress occurs (215). Hypoxia in the gastrointestinal tract, especially in the intestinal tissues, increases the permeability to pathogens and related endotoxins that cause oxidative stress damage $(216,217)$, which disturbs the function of the intestinal immune system, promotes deformation of mucous membranes and villi, and causes intestinal infections, which in turn lead to interruption of the digestion and absorption of nutrients $(218,219)$. Therefore, dietary Se supplementation to alleviate animal heat stress may be related to its ability to alleviate oxidative stress in the gastrointestinal tract and improve nutrient digestibility.

\section{Gastrointestinal Microbiome}

Growing evidence shows that interaction between hosts and their gastrointestinal microorganisms is involved in mammalian nutrient metabolism, immune homeostasis, and pathogen resistance (220, 221). For monogastric animals, it is reported that heat stress affects the structure and composition of the microbiota for from one week to several months (222-226). Xiong et al. (227) and He et al. (223) found that heat stress can increase the relative abundance of Proteobacteria, Gammaproteobacteria, Pseudomonadales, Moraxellaceae, and Acinetobactae in the intestines of pigs and ducks; Zhu et al. (226) found that heat stress increases the relative abundance of Bacteroidetes in the intestines of laying hens; Shi et al. (228) found that heat stress increased the relative abundance of Firmicutes, Tenericutes, and Proteobacteria in the intestines of broilers, but decreased the relative abundance of Bacteroidetes and 
Cyanobacteria; Qu et al. (229) found that heat stress increased the relative abundance of Oscillospira and Clostridium in murine intestines, but decreased the relative abundance of Lactobacillus and Bacteroides. Study have showed that the Lactobacillus was positively associated with serum total antioxidant, while some other microbial species were found negatively associated, such as Pseudomonadales and Acinetobacter (230). The increase of Firmicutes/Bacteroidetes ratio was considered to be a typical characteristic of obesity-driven dysbiosis in humans and animals (231). Thus, heat stress may affect animal health by affecting intestinal microorganism. There are still few studies on the effects of dietary Se supplement on the intestinal microbial ecosystem of heat stressed livestock. Further study could focus on this and provide a basis for moderating the heat stress of animals by regulating gastrointestinal microbes. Se in the intestine can enhance the intestinal environment for microorganisms by reducing local inflammation, and can also change susceptibility to infection caused by specific microorganisms (232). A small number of studies have evaluated the effects of dietary Se supplementation on the intestinal microbiota of fish $(233,234)$ and mammals. These studies confirmed that dietary Se supplementation has a positive effect on bacterial diversity in the intestine (234), produces an increase in beneficial bacteria number $(235,236)$, and reduces the frequency of intestinal infections (232).

In ruminants, rumen fermentation parameters are closely related to rumen microbes and can reflect their nutrient utilization. Under heat stress, lactating dairy cows significantly increased the production of lactic acid, decreased the production of total volatile acids and acetic acid, and decreased the $\mathrm{pH}$ of the rumen, which inhibited the activity of cellulolytic bacteria, resulting in a relative increase in Streptococci, Enterobacteriaceae, Ruminobacter, Treponema, and Bacteroidaceae in the rumen (199). Dietary Se can promote the growth of rumen microorganisms and rumen fermentation, and can significantly increase the production of propionic acid and total volatile acids. Previous studies have shown that the relative abundance of rumen bacteria, fungi, cellulose, and amylolytic bacteria (such as Ruminococcus, Fibrobacter, and Ruminococcus) increased after adding sodium selenate to the diet of lactating dairy cows; furthermore, the activity of cellobiase, carboxymethyl cellulase, xylanase, and protease were greatly promoted (214). The supplementation of yeast $\mathrm{Se}$ in the diet of sheep can increase the relative abundance of flora associated with rumen carbohydrate and protein metabolism (237). Therefore, dietary supplementation of Se may be related to its regulatory effect on gastrointestinal microbes. Future studies can further explore this hypothesis and clarify the role of Se supplementation in livestock diets and its interaction with gastrointestinal microbiota under heat stress.

\section{RESPONSE OF HEAT STRESS CELLS TO Se}

Research on the cellular effects of heat stress began in the 1970s. Results initially showed that heat stress could induce a variety of abnormalities in cell function, including cell membrane fluidity and stability, inhibition of receptors and transmembrane transporters (14), and even induction of oxidative damage and cell death (238). Under stress conditions, structural lipids such as phosphatidylcholine are hydrolyzed to produce phosphatidic acid $(239,240)$, and cleavage products such as the nonesterified fatty acid may be re-inserted into different membrane sites-leading to changes in membrane structure and membrane fluidity (241). Studies have confirmed that Se supplementation can protect cells from apoptosis induced by heat stress (175). Se regulates the expression of SELs, which participates in a series of cellular defense reactions, thereby protecting cells from stressors such as protein aggregates, heavy metal ions, heat shock, and oxidative damage (242-244).

\section{Intestinal Cells}

The intestinal epithelium plays an important role in the digestion and absorption of nutrients and the development of immune function (245). Studies have shown that reducing the integrity of the intestinal barrier and increasing intestinal permeability through heat stress endangers the health of livestock and their production performance $(127,236,246)$. Heat stress will increase the concentration of intestinal endotoxins and pathogenic bacteria in the portal vein and systemic blood (214), leading to gastrointestinal damage and eventual death from heat exhaustion $(247,248)$. As mentioned above, Se supplementation can reduce intestinal epithelial cell damage induced by heat stress $(55,74$, 249, 250).

Heat stress can damage intestinal barrier function, leading to an increase in permeability, and the concentration of lipopolysaccharides in the portal vein and systemic blood (215). Intestinal epithelial cells are closely bound together by tight junction proteins between cells; the latter regulate the permeability of cells and are essential units in the epithelial barrier. Tight junctions are complex structures composed of more than 50 proteins. Studies on the expression of three tight junction proteins: claudin 1, occludin, and zonula occludens-1 (ZO-1) have shown that supplementation of SeMet reduces the down-regulation of ZO-1 and claudin 1 expression under heat stress conditions. Furthermore, SS supplementation alleviates the down-regulation of claudin 1 expression caused by heat stress (175). claudin 1 is a tightly connected structural skeleton and seals the space between two adjacent epithelial cells (251). ZO-1 is a plaque protein that combines with other proteins to form a scaffold or interacts with specific transmembrane proteins to stabilize them in the cytoplasm (252). Interestingly, the first PDZ structural domain of ZO-1 interacts with claudin 1 protein (253), and a decrease in gene and protein expression indicates an increase in the permeability of the epithelial barrier. Both SS and SeMet supplements effectively slowed down the damage of tight junctions, and SeMet even increased the expression of these two tight junction proteins in IPEC-J2 cells exposed to heat stress (175). In addition, occludin mainly regulates the intermembrane diffusion and paracellular diffusion of small molecules (254), while SS and SeMet supplementation has no 
significant effect on the protein expression of occludin in IPECJ2 cells under heat stress (175).

Cells accumulate HSP70 when undergoing heat stress and increased lipid peroxidation, which may serve as a tissue biomarker of potential damage caused by stress (255). In other words, an increase in HSP70 expression usually indicates an increase in the intensity of heat stress. In addition, HSP70 plays a key role in the process of heat resistance by maintaining cell homeostasis $(256,257)$ as it can protect cells from endotoxemia, hypoxia, and metabolic stress (258); inhibit the activation of caspase 3 to prevent heat stress-induced cells apoptosis (259, 260); and activate protein kinase B (Akt) to promote cell survival (261). It is reported that heat stress significantly increases the expression of HSP70 in rat intestinal epithelial IEC-18 cells, which may play a role in protecting such cells from oxidation and heat damage (262). Study showed that SeMet supplementation promotes the expression of HSP70 mRNA and protein in IPEC-J2 cells under heat stress, indicating that it has a beneficial effect on intestinal epithelial cells, i.e., Se reduces heat stress, so cells do not need to synthesize relatively more HSP70 protein to combat heat damage (175).

Heat stress can damage the integrity of the intestinal epithelial barrier of pigs $(210,217,263)$, and its mechanism may involve oxidative stress. Although the intestinal oxidative stress markers are closely related to the duration and intensity of heat stress, their expression in the intestinal tract of heat-stressed rats (264, 265) and pigs (209) is significantly increased. Oxidative stress destroys tight junctions (266) and reduces the viability of epithelial cells (258), so it may play a role in the integrity of the porcine intestinal barrier induced by heat stress. Dietary supplements that can alleviate oxidative stress can prevent heat stress caused by intestinal barrier dysfunction. Studies have shown that the expression of SEL in IPEC-J2 cells is affected by heat stress (161). Heat stress induces the expression of 10 SELrelated genes. These genes play an important role in antioxidation by promoting hydrogen peroxide metabolism and regulating the level of intracellular stress (161). Study confirmed that heat stress enhances intestinal oxidative stress and reduces barrier integrity, while high levels of dietary Se and $\mathrm{VE}$ can reduce the occurrence of oxidative stress and intestinal leakage (133). Studies have shown that Se yeast supplements enhance the resistance of poultry to oxidative stress and high temperature exposure associated with intestinal bacterial infections. This effect is closely related to the improvement of the body's redox state after Se supplementation (267). In addition, related studies confirmed that the addition of Se to a cell culture medium of caco- 2 significantly increased mRNA expression levels of GPx1, thioredoxin reductase (TrxR) 1, and SelP (268). Moreover, supplementation of hydroxyselenomethionine promotes the protein expression of GPx4, thioredoxin reductase (TXNRD) 1, and SELS and downregulates the expression of seven inflammation-related genes in jejunal mucosa affected by heat stress (134).

The above results suggest that Se supplementation can enhance antioxidant capacity, and thus mitigate damage to the intestinal epithelial barrier of livestock under heat stress. This information provides a research base for alleviating heat stress induced intestinal injury and improving livestock intestinal health.

\section{Other Cells}

The main function of HSP is to resist the effects of stress on cells (269). Heat shock factor (HSF) 1 leads to the expression of stressinduced genes, and HSP90 is the main defense protein against heat stress $(270,271)$. Under normal circumstances, HSF1 combines with HSP (usually HSP90). When cells are stimulated, HSP separates from HSF1. HSF1 subsequently enters the nucleus and induces downstream heat shock elements to regulate gene expression (272). Studies have shown that the expression of HSF1 and HSP90 genes in bovine mammary epithelial (MAC-T) cells are notably increased after heat shock. Se pretreatment reversed this effect (190), and Se deficiency also increased the level of HSP in chicken livers (273) and the expression of HSP90 in chicken red blood cells (274).

Studies have found that heat stress can increase the production of ROS, which in turn disturbs the steady state of redox balance, leading to oxidative stress in cells (14). Dietary supplementation with Se can increase the activity of glutathione peroxidase in lactating dairy cows and enhance the ability of the antioxidant system (275). Studies have confirmed that oxidative stress in MAC-T cells after heat shock increases the production of ROS and reduces the activities of SOD and total antioxidant capacity (T-AOC), while Se pretreatment can significantly improve the antioxidant effect of MAC-T cells (190). In addition, heat shock and Se pretreatment can affect the expression of $\mathrm{HO}-1$. The endogenous carbon monoxide produced by $\mathrm{HO}-1$ activates $\mathrm{Akt} / \mathrm{PKB}$ (protein kinase B). Akt has a negative effect on GSK-3 $\beta$ (glycogen synthase kinase $3 \beta$ ) that activates nuclear factor E2-related factor 2 (Nrf2) (276). $\mathrm{Nrf2}$ is a major transcription factor that regulates the expression of antioxidant proteins. Under oxidative stress, its ubiquitination stops and it translocate into the nucleus where it combines with antioxidant response elements, ultimately activating the defense system (277). TXNRD1 is an intracellular SEL and an isoenzyme that provides one of the main enzyme defense systems for ROS in vascular endothelial cells. Studies have found that different forms of Se tend to activate different genes in the Nrf2-antioxidant pathway of dairy cow arterial endothelial cells: SM pretreatment tends to inhibit the expression of $\mathrm{Nrf} 2$, while SS tends to reduce the protein level of TXNRD1 (278).

Studies have found that environmental factors greatly affect cell differentiation (279). In the differentiation of mouse myoblasts, Se supplementation reduces the negative effect of heat stress on the myogenic differentiation of $\mathrm{C} 2 \mathrm{C} 12$ cells to a certain extent. This process may be related to the change of SEL expression pattern and the effect of SeMet is superior to that of SS (280). It was shown that heat stress increases the expression of most SEL-encoding genes in myoblast (C2C12) cells (281). Among them: the GPx family can use glutathione to catalyze the reduction of hydrogen peroxide and lipid hydroperoxide (282); iodothyronine deiodinase 2 is located in the endoplasmic reticulum (ER) membrane (283) and is an oxidoreductase that 
participates in thyroid hormone metabolism by catalyzing the activation of tetraiodothyroxine to triiodothyronine (284); SELS and SELK have similar structural features, and they participate in the ER-related degradation of unfolded and misfolded proteins (285); SELT, known as glycosylated transmembrane protein, may have potential functions related to SELW. Studies have shown that: increasing the expression of SELW can compensate for the knockdown of SELT in mouse fibroblasts (286); SEL15 contains a Cys-rich domain in the N-terminal of the protein, which may play a role in catalyzing isomerization or reduction of disulfide bonds (287); the protein encoded by selenophosphate synthase 2 participates in the biosynthesis of SELs, can catalyze the synthesis of monoselenophosphate, and is the main donor of Se (147). Follow-up studies can focus on the expression of the above SELs and further explore the interaction between Se supplementation and heat stress-induced muscle cell damage.

\section{DIETARY SUPPLEMENTATION OF Se TO IMPROVE THE REPRODUCTIVE PHYSIOLOGY OF HEAT STRESSED LIVESTOCK}

\section{Female Livestock}

Heat stress is the main risk factor that affects the reproductive efficiency and production performance of female mammals in summer $(14,288)$. Existing evidence shows that heat stress can cause abnormal atresia of follicles in the ovary, impaired secretion of ovarian steroid hormones, and even lead to infertility (289). Heat stress can cause a significant increase in body temperature and a decrease in egg production, egg weight, ovarian weight, and follicle number (70). Compared with acute heat stress, the impact of chronic heat stress is relatively weak, but owing to its lengthy duration, it also brings serious economic losses to the livestock industry (137). Granulosa cell apoptosis is an important marker and inducer of follicular atresia, and it plays a vital role in maintaining normal ovarian follicular growth, hormone synthesis, and other physiological functions (290). Heat stress inhibits the proliferation of ovarian granulosa cells and induces their apoptosis, which is closely related to the ovarian dysfunction caused by heat stress in various species (291-293); that is, maintaining normal physiological functions of granulosa cells under heat stress may help prevent or reduce ovarian damage caused by heat stress. In addition, in eukaryotes, the endoplasmic reticulum is an important organelle for the folding, modification, and maturation of new and mature proteins.

Many pathological factors can disturb the balance between the protein load and folding ability of the endoplasmic reticulum, which can trigger endoplasmic reticulum stress (294-296). If homeostasis of the endoplasmic reticulum microenvironment is not restored, severe or continuous endoplasmic reticulum stress will eventually induce cell apoptosis (297). There is accumulating evidence that endoplasmic reticulum stress is related to various pathological reactions caused by reproductive diseases and heat stress-induced cell death. Previous studies have shown that endoplasmic reticulum stress-mediated apoptosis of granulosa cells plays an important role in the progression of follicular atresia through $78-\mathrm{kD}$ glucose-regulated protein (GRP78) and CHOP activation in the goat ovary (298). Owing to its antioxidant function, Se has been widely used to regulate metabolic disorders and reproductive physiological functions, such as effectively protecting certain cells from apoptosis induced by poisons and endoplasmic reticulum stress (35). Studies have confirmed that heat stress can reduce the viability of mouse granulosa cells and increase the expression of caspase3, which induces apoptosis, and key apoptosis-related proteins B-cell lymphoma-2-associated X protein and ER stress activation markers GRP78 and CHOP. Sodium selenite can significantly inhibit the decrease in cell viability induced by chronic heat stress, increase the protein expression levels of apoptosis-related genes and endoplasmic reticulum stress activation markers, and inhibit the decrease in estradiol expression in heat stress-induced granulosa cells (299).

\section{Male Livestock}

For male animals, heat stress can change the structure and weight of the testicles, reduce the number of sperms, reduce sperm quality, and cause abnormal sperm morphology and DNA fragmentation (300). The negative effect of heat stress on male fertility is related to the production of ROS (301). For example, studies have found that acute heat stress increases the oxidative stress and ROS levels of SOD 1 knockout mice, where even exposure to $42 \mathrm{C}$ for 15 minutes can cause damage to sperm (136). Therefore, the use of antioxidants may mitigate the negative impact of heat stress on male fertility. The function of $\mathrm{Se}$ in the male reproductive tract is independent of other physiological processes in the body. Se acts on the reproductive organs and participates in the biosynthesis of testosterone and the formation and development of sperm (302). In addition, Se is a component of at least 25 SELs, including glutathione peroxidase and other functional and structural proteins of the testis, epididymis, and sperm $(303,304)$. For example: GPx1 and GPx3 are expressed and located in epididymal epithelia and sperm to protect epididymal parenchyma and mature sperm from oxidative stress; GPx4 can protect developing sperm from DNA damage caused by oxidative stress, it is also a structural component of the middle mitochondrial sheath of sperm and is an important part of sperm stability and motility (305).

Studies have shown that under heat stress, supplementation of $0.3 \mathrm{mg}$ OSe/kg DM in basal diet for rabbits can improve heat tolerance and health status, thereby significantly improving semen quality and subsequent fertility (306). Moreover, the body's antioxidant/pro-oxidant balance is considered a key determinant of chicken health, embryonic development, sperm quality, and possible production and reproduction characteristics of poultry $(307,308)$. Studies have found that supplementing organic Se in the diets of heat-stressed roosters increases the number and vitality of sperm, reduces the mortality of sperm, and enhanced the antioxidant status of seminal plasma, thereby improving the quality of seminal fluid (309). Furthermore, the 
combination of dietary vitamin $\mathrm{E}$ and organic Se has a synergistic effect in reducing lipid peroxidation and improving the antioxidant status of poultry seminal plasma, which is specifically increases the number and vitality of sperm under heat stress conditions and reduces sperm mortality rate (310).

\section{CONCLUSION}

In this review, we summarized the effect of Se as dietary source on heat stressed livestock, while focusing on the performance, inflammation, reproduction and cell damage, as well as the main regulatory mechanism, that is, regulating gastrointestinal microorganisms, nutrient digestibility, antioxidant status, cell damage, and immune capacity of livestock. Hence, Se supplement could serve as a nutritional strategy to help animals to reduce negative effects on their production performances and health during heat stress period.

\section{REFERENCES}

1. Bernabucci U, Lacetera N, Baumgard LH, Rhoads RP, Ronchi B, Nardone A. Metabolic and Hormonal Acclimation to Heat Stress in Domesticated Ruminants. Animal (2010) 4:1167-83. doi: 10.1017/S175173111000090X

2. Bernabucci U, Basirico L, Morera P, Lacetera N, Ronchi B, Nardone A. Heat Shock Modulates Adipo-Kines Secretion in 3T3-L1 Adipocytes. $\mathrm{J} \mathrm{Mol}$ Endocrinol (2009) 42:139-47. doi: 10.1677/jme-08-0068

3. Morera P, Basirico L, Hosoda K, Bernabucci U. Chronic Heat Stress UpRegulates Leptin and Adiponectin Secretion and Expression and Improves Leptin, Adiponectin and Insulin Sensitivity in Mice. Journal of Molecular Endocrinology. J Mol Endocrinol (2012) 48:129-38. doi: 10.1530/JME-11-0054

4. Lewandowska A, Gierszewska M, Marszalek J, Liberek K. Hsp78 Chaperone Functions in Restoration of Mitochondrial Network Following Heat Stress. Biochim Biophys Acta (2006) 1763:141-51. doi: 10.1016/j.bbamcr.2006.01.007

5. Mujahed A, Pumfordn NR, Bottje W, Nakagawa K, Miyazawa T, Akiba M, et al. Mitochondrial Oxidative Damage in Chicken Skeletal Muscle Induced by Acute Heat Stress. J Poult Sci (2007) 44:439-45. doi: 10.2141/jpsa.44.439

6. Du J, Di HS, Guo L, Li ZH, Wang GL. Hyperthermia Causes Bovine Mammary Epithelial Cell Death by a Mitochondrial-Induced Pathway. J Therm Biol (2008) 33:37-47. doi: 10.1016/j.jtherbio.2007.06.002

7. Lord-Fontaine S, Averill-Bates DA. Heat Shock Inactivates Cellular Antioxidant Defense Against Hydrogen Peroxide: Protection by Glucose. Free Radical Bio Med (2002) 32:752-65. doi: 10.1016/S0891-5849(02)00769-4

8. Stadtman ER, Levine RL. Protein Oxidation. Ann Ny Acad Sci (2010) 899:191208. doi: 10.1111/j.1749-6632.2000.tb06187.x

9. Rubbo H, Radi R, Trujillo M, Telleri R, Kalyanaraman B, Barnes S, et al. Nitric Oxide Regulation of Superoxide and Peroxynitrite-Dependant Lipid Peroxidation. Formation of Novel Nitrogen-Containing Oxidized Lipid Derivatives. J Biol Chem (1994) 269:26066-75. doi: 10.1016/0092-8674(94)90204-6

10. Kaur H, Halliwell B. Evidence for Nitric Oxide-Mediated Oxidative Damage in Chronic Inflammation: Nitrotyrosine in Serum and Synovial Fluid From Rheumatoid Patients. FEBS Lett (1994) 350:9-12. doi: 10.1016/0014-5793(94) 00722-5

11. LeDoux SP, Driggers WJ, Hollensworth BS, Wilson GL. Repair of Alkylation and Oxidative Damage in Mitochondrial DNA. Mutat Res (1999) 434:149-59. doi: 10.1016/S0921-8777(99)00026-9

12. Kumar A, Singh G, Sunil Kumar BV, Meur SK. Modulation of Antioxidant Status and Lipid Peroxidation in Erythrocyte by Dietary Supplementation During Heat Stress in Buffaloes. Livest Sci (2011) 138:299-303. doi: 10.1016/ j.livsci.2010.12.021

13. Pandey N, Kataria N, Kumar Kataria A, Joshi A, Narayan Sankhala L, Asopa S, et al. Extreme Ambiances Vis-À-Vis Endogenous Antioxidants of Marwari Goat From Arid Tracts in India. ELBA Bioflux (2012) 4:29-33.

\section{AUTHOR CONTRIBUTIONS}

YZ and TX wrote the article. YW, ZC, HY, WW, and SL reviewed and provided guidance for the manuscript.

\section{FUNDING}

This work was supported by Guiding Local Science and Technology Development Projects by the Central Government (NO.GKZY20111004) and by China Agriculture Research System of MOF and MARA.

\section{ACKNOWLEDGMENTS}

We thank the support of State Key Laboratory of Animal Nutrition in China Agricultural University.

14. Belhadj SI, Najar T, Ghram A, Abdrrabba M. Heat Stress Effects on Livestock: Molecular, Cellular and Metabolic Aspects, a Review. J Anim Physiol Anim Nutr (Berl) (2016) 100:401-12. doi: 10.1111/jpn.12379

15. Hambuckers A, Dotreppe O. Istasse. Problem of Applying Sodium Selenate to Increase Selenium Concentration in Grassland Plants in Southern Belgium. Commun Soil Sci Plant Anal (2010) 41:1283-92. doi: 10.1080/ 00103621003759296

16. Tinggi U. Essentiality and Toxicity of Selenium and its Status in Australia: A Review. Toxicol Lett (2003) 137:103-10. doi: 10.1016/S0378-4274(02)00384-3

17. Mehdi Y, Hornick JL, Istasse L, Dufrasne I. Selenium in the Environment, Metabolism and Involvement in Body Functions. Molecules (2013) 18:3292311. doi: 10.3390/molecules 18033292

18. Barceloux DG. Selenium. J Toxicol Clin Toxicol (1999) 37:145-72. doi: 10.1081/CLT-100102417

19. Wen H, Carignan J. Reviews on Atmospheric Selenium: Emissions, Speciation and Fate. Atmospheric Environ (2007) 41:7151-65. doi: 10.1016/j.atmosenv. 2007.07.035

20. Graham TW. Trace Element Deficiencies in Cattle. Vet Clin North Am Food Anim Pract (1991) 7:153-215. doi: 10.1016/S0749-0720(15)30816-1

21. Chao YM, Yu B, He J, Huang ZQ, Mao XB, Luo JQ, et al. Effects of Different Levels of Dietary Hydroxy-Analogue of Selenomethionine on Growth Performance, Selenium Deposition and Antioxidant Status of Weaned Piglets. Arch Anim Nutr (2019) 73:374-83. doi: 10.1080/1745039X.2019. 1641368

22. Meschy F. Nutrition Minérale Des Ruminants. Books.Google.Com. Versaille, France: Editions Quae. (2010). pp. 208-10.

23. Kessler J. Carence En Sélénium Chez Les Ruminants: Mesures Prophylactiques. Rev Suisse Agric (1993) 25:21-6.

24. Mistry HD, Pipkin FB, Redman CW, Poston L. Selenium in Reproductive Health. Am J Obstet Gynecol (2012) 206:21-30. doi: 10.1016/j.ajog.2011.07.034

25. Shakeri M, Oskoueian E, Le HH, Shakeri M. Strategies to Combat Heat Stress in Broiler Chickens: Unveiling the Roles of Selenium, Vitamin E and Vitamin C. Vet Sci (2020) 7:71-80. doi: 10.3390/vetsci7020071

26. Arshad MA, Ebeid HM, Hassan FU. Climate Change and Australian Livestock Systems: Impacts, Research and Policy Issues: A Review. Biol Trace Elem Res (2021) 199:3319-37. doi: 10.1007/s12011-020-02480-6

27. Burk RF. Selenium in Biology and Human Health. New York: Springer-Verlag New York Inc (1994).

28. Finch JM, Turner RJ. Effects of Selenium and Vitamin E on the Immune Responses of Domestic Animals. Res Vet Sci (1996) 60:97-106. doi: 10.1016/ S0034-5288(96)90001-6

29. Sordillo LM. Selenium-Dependent Regulation of Oxidative Stress and Immunity in Periparturient Dairy Cattle. Vet Med Int (2013) 2013: e154045-e154053. doi: 10.1155/2013/154045 
30. Davis CD, Tsuji PA, Milner JA. Selenoproteins and Cancer Prevention. Annu Rev Nutr (2012) 32:73-95. doi: 10.1146/annurev-nutr-071811-150740

31. Koyama H, Mutakin AR, Yamazaki C, Kameo S. Selenium Supplementation Trials for Cancer Prevention and the Subsequent Risk of Type 2 Diabetes Mellitus. Nihon Eiseigaku Zasshi Jpn J Hyg (2013) 68:1-10. doi: 10.1016/j.ifset.2013.05.006

32. Rayman MP. Selenium and Human Health. Lancet (2012) 379:1256-68. doi: 10.1016/S0140-6736(11)61452-9

33. Fairweather-Tait SJ, Bao Y, Broadley MR, Collings R, Ford D, Hesketh JE, et al. Selenium in Human Health and Disease. Antioxid Redox Signal (2011) 14:1337-83. doi: 10.1089 /ars.2010.3275

34. Harrison JH, Russell CH. Effect of Dietary Calcium on Selenium Absorption by the Nonlactating Dairy Cow. J Dairy Sci (1984) 67:1860-4. doi: 10.3168/ jds.S0022-0302(84)81514-3

35. Spears JW, Weiss WP. Role of Antioxidants and Trace Elements in Health and Immunity of Transition Dairy Cows. Vet J (2008) 176:70-6. doi: 10.1016/ j.tvjl.2007.12.015

36. Suttle NF. Mineral Nutrition of Livestock. Cabi Bookshop (2009) 215:1-8. doi: $10.1079 / 9781845934729.0000$

37. Hoffmann PR. Mechanisms by Which Selenium Influences Immune Responses. Arch Immunol Ther Exp (2007) 55:289-97. doi: 10.1007/s00005-007-0036-4

38. Best B. Selenium: Antioxidant, Anti-Carcinogen, and Immune System Booster (2007). Available at: http://www.benbest.com/nutrceut/Selenium.html.

39. Howden SM, Crimp SJ, Stokes CJ. Climate Change and Australian Livestock Systems: Impacts, Research and Policy Issues. Aust J Exp Agric (2008) 48:7808. doi: 10.1071/EA08033

40. Renaudeau D, Gourdine JL, St-Pierre NR. A Meta-Analysis of the Effects of High Ambient Temperature on Growth Performance of Growing-Finishing Pigs. J Anim Sci (2011) 89:2220-30. doi: 10.2527/jas.2010-3329

41. Nardone A, Ronchi B, Lacetera N, Ranieri MS, Bernabucci U. Effects of Climate Change on Animal Production and Sustainability of Livestock Systems. Livest Sci (2010) 130:57-69. doi: 10.1016/j.livsci.2010.02.011

42. Henry B, Charmley E, Eckard R, Gaughan JB, Hegarty R. Livestock Production in a Changing Climate: Adaptation and Mitigation Research in Australia. Crop Pasture Sci (2012) 63:191-202. doi: 10.1071/CP11169

43. Lacetera N. Impact of Climate Change on Animal Health and Welfare. Anim Front (2018) 9:26-31. doi: 10.1093/af/vfy030

44. St-Pierre NR, Cobanov B. Schnitkey G Economic Losses From Heat Stress by US Livestock Industries. J Dairy Sci (2003) 86:E52-77. doi: 10.3168/jds.S00220302(03)74040-5

45. Mujahid A, Akiba Y, Toyomizu M. Olive Oil-Supplemented Diet Alleviates Acute Heat Stress-Induced Mitochondrial ROS Production in Chicken Skeletal Muscle. Am J Physiol Regul Integr Comp Physiol (2009) 297:R6908. doi: 10.1152/ajpregu.90974.2008

46. Azad MAK, Kikusato M, Maekawa T, Shirakawa H, Toyomizu. Metabolic Characteristics and Oxidative Damage to Skeletal Muscle in Broiler Chickens Exposed to Chronic Heat Stress. Comp Biochem Physiol Part A (2010) 155:401-6. doi: 10.1016/j.cbpa.2009.12.011

47. Skrivan M, Marounek M, Englmaierova M, Skrivanova E. Influence of Dietary Vitamin $\mathrm{C}$ and Selenium, Alone and in Combination, on the Composition and Oxidative Stability of Meat of Broilers. Food Chem (2012) 130:660-4. doi: 10.1016/j.foodchem.2011.07.103

48. Wang YX, Zhan XA, Zhang XW, Wu RJ, Yuan D. Comparison of Different Forms of Dietary Selenium Supplementation on Growth Performance, Meat Quality, Selenium Deposition, and Antioxidant Property in Broilers. Biol Trace Elem Res (2011) 143:261-73. doi: 10.1007/s12011-010-8839-2

49. Wang YB, Xu BH. Effect of Different Selenium Source (Sodium Selenite and Selenium Yeast) on Broiler Chickens. Anim Feed Sci Technol (2008) 144:30614. doi: 10.1080/00071668.2020.1716301

50. Swain BK, Johri TS, Majumdar S. Effect of Supplementation of Vitamin E, Selenium and Their Different Combinations on the Performance and Immune Response of Broilers. Br Poult Sci (2000) 41:287-92. doi: 10.1080/713654938

51. Rao SVR, Prakash B, Raju MVLN, Panda AK, Kumari RK, Reddy EPK. Effect of Supplementing Organic Forms of Zinc, Selenium and Chromium on Performance, Anti-Oxidant and Immune Responses in Broiler Chicken Reared in Tropical Summer. Biol Trace Elem Res (2016) 172:511-20. doi: 10.1007/s12011-015-0587-x

52. Spencer JD, Boyd RD, Cabrera R, Allee GL. Early Weaning to Reduce Tissue Mobilization in Lactating Sows and Milk Supplementation to Enhance Pig
Weaning Weight During Extreme Heat Stress. J Anim Sci (2003) 81:2041-52. doi: $10.2527 / 2003.8182041 \mathrm{x}$

53. Song Z, Liu L, Sheikhahmadi A, Jiao H, Lin H. Effect of Heat Exposure on Gene Expression of Feed Intake Regulatory Peptides in Laying Hens. J BioMed Biotechnol (2012) 2012:484869-8. doi: 10.1155/2012/484869

54. Sahin K, Sahin N, Yaralioglu S, Onderci M. Protective Role of Supplemental Vitamin E and Selenium on Lipid Peroxidation, Vitamin E, Vitamin A, and Some Mineral Concentrations of Japanese Quails Reared Under Heat Stress. Biol Trace Elem Res (2002) 85:59-70. doi: 10.1385/BTER:85:1:59

55. Sahin K, Kucuk O. Effects of Vitamin E and Selenium on Performance, Digestibility of Nutrients and Carcass Characteristics of Japanese Quails Reared Under Heat Stress $\left(34^{\circ} \mathrm{C}\right)$. J Anim Physiol Anim Nutr (2001) 85:342-8. doi: 10.1046/j.1439-0396.2001.00340.x

56. Sheiha AM, Abdelnour SA, Abd El-Hack ME, Khafaga AF, Metwally KA, Ajarem JS, et al. Effects of Dietary Biological or Chemical-Synthesized NanoSelenium Supplementation on Growing Rabbits Exposed to Thermal Stress. Anim (Basel) (2020) 10:430-46. doi: 10.3390/ani10030430

57. Hassan F, Mobarez S, Mohamed M, Attia Y, Mekawy A, Mahrose K. Zinc and/ or Selenium Enriched Spirulina as Antioxidants in Growing Rabbit Diets to Alleviate the Deleterious Impacts of Heat Stress During Summer Season. Anim (Basel) (2021) 11:756-67. doi: 10.3390/ani11030756

58. Alhidary IA, Shini S, Al Jassim RA, Abudabos AM, Gaughan JB. Effects of Selenium and Vitamin E on Performance, Physiological Response, and Selenium Balance in Heat-Stressed Sheep. J Anim Sci (2015) 93:576-88. doi: $10.2527 /$ jas.2014-8419

59. Stapleton SR. Selenium: An Insulin-Mimetic. Cell Mol Life Sci (2000) 57:18749. doi: 10.1007/PL00000669

60. Alhidary IA, Shini S, Jassim RA, Gaughan JB. Effect of Various Doses of Injected Selenium on Performance and Physiological Responses of Sheep to Heat Load. J Ani Sci (2012) 90:2988-894. doi: 10.2527/jas.2011-4908

61. Schrama JW, Heetkamp MJW, Simmins PH, Gerrits WJJ. Dietary Betaine Supplementation Affects Energy Metabolism of Pigs. J Ani Sci (2003) 81:12029. doi: 10.1051 /gse:2003012

62. Liu F, Celi P, Cottrell JJ, Chauhan SS, Leury BJ, Dunshea FR. Effects of a ShortTerm Supranutritional Selenium Supplementation on Redox Balance, Physiology and Insulin-Related Metabolism in Heat-Stressed Pigs. J Anim Physiol n (2017) 102:1-10. doi: 10.1111/jpn.12689

63. Abdel-Moneim AE, Shehata AM, Mohamed NG, Elbaz AM, Ibrahim NS. Synergistic Effect of Spirulina Platensis and Selenium Nanoparticles on Growth Performance, Serum Metabolites, Immune Responses, and Antioxidant Capacity of Heat-Stressed Broiler Chickens. Biol Trace Elem Res (2021) 2021:768-79. doi: 10.1007/s12011-021-02662-w

64. Bartlett JR, Smith MO. Effects of Different Levels of Zinc on the Performance and Immunocompetence of Broilers Under Heat Stress. Poult Sci (2003) 82:1580-8. doi: $10.1093 / \mathrm{ps} / 82.10 .1580$

65. Sahin K, Kucuk O. Heat Stress and Dietary Vitamin Supplementation of Poultry Diets. Nutr Abstr Rev (2003) 73:41R-50R.

66. Yang Y, Li C, Xiang X. Ursolic Acid Prevents Endoplasmic Reticulum StressMediated Apoptosis Induced by Heat Stress in Mouse Cardiac Myocytes. J Mol Cell Cardiol (2014) 67:103-11. doi: 10.1016/j.yjmcc.2013.12.018

67. Pearce SC, Gabler NK, Ross JW, Escobar J, Patience JF, Rhoads RP, et al. The Effects of Heat Stress and Plane of Nutrition on Metabolism in Growing Pigs. J Anim Sci (2013) 91:2108-18. doi: 10.2527/jas.2012-5738

68. Smith AJ, Oliver O. Some Nutritional Problems Associated With Egg Production at High Environmental Temperatures. I. The Effect of Environmental Temperature and Rationing Treatments in the Productivity of Pullets Fed on Diets of Differing Energy Content. Rhod J Agric Res (1972) 10:3-20.

69. Donkoh A. Ambient Temperature: A Factor Affecting Performance and Physiological Response of Broiler Chickens. Int J Biometeorol (1989) 33:259-65. doi: 10.1007/BF01051087

70. Rozenboim I, Tako E, Gal-Garber O, Proudman JA, Uni Z. The Effect of Heat Stress on Ovarian Function of Laying Hens. Poult Sci (2007) 86:1760-5. doi: $10.1093 / \mathrm{ps} / 86.8 .1760$

71. Sahin N, Onderci M, Sahin K, Kucuk O. Supplementation With Organic or Inorganic Selenium in Heat-Distressed Quail. Biol Trace Elem Res (2008) 122:229-37. doi: 10.1007/s12011-007-8075-6

72. Ibrahim M. Eljack B. Fadlalla I. Selenium Supplementation to Broiler Diets. Anim Sci J (2011) 2:12-7. 
73. Krstić B, Jokić Ž, Pavlović Z, Živković D. Options for the Production of Selenized Chicken Meat. Biol Trace Elem Res (2012) 146:68-72. doi: 10.1007/ s12011-011-9229-0

74. Niu Z, Liu F, Yan Q, Li L. Effects of Different Levels of Selenium on Growth Performance and Immunocompetence of Broilers Under Heat Stress. Arch Anim Nutr (2009) 63:56-65. doi: 10.1080/17450390802611610

75. Habibian M, Ghazi S, Moeini MM. Effects of Dietary Selenium and Vitamin E on Growth Performance, Meat Yield, and Selenium Content and Lipid Oxidation of Breast Meat of Broilers Reared Under Heat Stress. Biol Trace Elem Res (2016) 169:142-52. doi: 10.1007/s12011-015-0404-6

76. Tayeb I, Qader GK. Effect of Feed Supplementation of Selenium and Vitamin E on Production Performance and Some Hematological Parameters of Broiler. Kahramanmaras Sutcu Imam Univ J Nat Sci (2012) 15:46-56. doi: 10.13140/ RG.2.2.32719.12966

77. Zeferino CP, Komiyama CM, Pelícia VC, Fascina VB, Aoyagi MM, Coutinho LL, et al. Carcass and Meat Quality Traits of Chickens Fed Diets Concurrently Supplemented With Vitamins C and E Under Constant Heat Stress. Animal (2016) 10:163-71. doi: 10.1017/S1751731115001998

78. Ghazi S, Habibian M, Moeini MM, Abdolmohammadi A. Effects of Dietary Selenium, Vitamin E, and Their Combination on Growth, Serum Metabolites, and Antioxidant Defense System in Skeletal Muscle of Broilers Under Heat Stress. Biol Trace Elem Res (2012) 148:322-30. doi: 10.1007/ s12011-012-9374-0

79. Mikulski D, Jankowski J, Zduńczyk Z, Wróblewska M, Sartowska K, Majewska T. The Effect of Selenium Source on Performance, Carcass Traits, Oxidative Status of the Organism, and Meat Quality of Turkeys. J Anim Feed Sci (2009) 18:518-30. doi: 10.22358/jafs/66427/2009

80. Hashizawa Y, Kubota M, Kadowaki M, Fujimura S. Effect of Dietary Vitamin E on Broiler Meat Qualities, Color, Water-Holding Capacity and Shear Force Value, Under Heat Stress Conditions. Anim Sci J (2013) 84:732-6. doi: 10.1111/ asj. 12079

81. Gregory NG. How Climatic Changes Could Affect Meat Quality. Food Res Int (2010) 43:1866-73. doi: 10.1016/j.foodres.2009.05.018

82. Chauhan SS, Celi P, Ponnampalam EN, Leury BJ, Liu F, Dunshea FR. Antioxidant Dynamics in the Live Animal and Implications for Ruminant Health and Product (Meat/Milk) Quality: Role of Vitamin E and Selenium. Anim Prod Sci (2014) 54:1525-36. doi: 10.1071/AN14334

83. Akşit M, Yalcin S, Özkan S, Metin K, Özdemir D. Effects of Temperature During Rearing and Crating on Stress Parameters and Meat Quality of Broilers. Poult Sci (2006) 85:1867-74. doi: 10.1093/ps/85.11.1867

84. Wang R, Pan X, Peng Z. Effects of Heat Exposure on Muscle Oxidation and Protein Functionalities of Pectoralis Majors in Broilers. Poult Sci (2009) 88:1078-84. doi: 10.3382/ps.2008-00094

85. Chan JT, Omana DA, Betti M. Effect of Ultimate $\mathrm{pH}$ and Freezing on the Biochemical Properties of Proteins in Turkey Breast Meat. Food Chem (2011) 127:109-17. doi: 10.1016/j.foodchem.2010.12.095

86. Bragagnolo N, Danielsen B, Skibsted LH. Combined Effect of Salt Addition and High-Pressure Processing on Formation of Free Radicals in Chicken Thigh and Breast Muscle. Euro Food Res Technol (2006) 223:669-73. doi: 10.1007/s00217-006-0251-y

87. Chauhan SS, Dunshea FR, Plozza TE, Hopkins DL, Ponnampalam EN. The Impact of Antioxidant Supplementation and Heat Stress on Carcass Characteristics, Muscle Nutritional Profile and Functionality of Lamb Meat. Anim (Basel) (2020) 10:1286-97. doi: 10.3390/ani10081286

88. Haug A, Eich-Greatorex S, Bernhoft A, Wold JP, Hetland H, Christophersen OA, et al. Effect of Dietary Selenium and Omega-3 Fatty Acids on Muscle Composition and Quality in Broilers. Lipids Health Dis (2007) 6:29-38. doi: 10.1186/1476-511X-6-29

89. Ševčíková S, Skřivan M, Dlouhá G, Koucký M. The Effect of Selenium Source on the Performance and Meat Quality of Broiler Chickens. Czech J Anim Sci (2006) 51:449-57. doi: 10.1080/00071660600970813

90. Amer SA, Omar AE, Abd El-Hack ME. Effects of Selenium- and ChromiumEnriched Diets on Growth Performance, Lipid Profile, and Mineral Concentration in Different Tissues of Growing Rabbits. Biol Trace Elem Res (2018) 187:92-9. doi: 10.1007/s12011-018-1356-4

91. Kelman KR, Pannier L, Pethick DW, Gardner GE. Selection for Lean Meat Yield in Lambs Reduces Indicators of Oxidative Metabolism in the
Longissimus Muscle. Meat Sci (2014) 96:1058-67. doi: 10.1016/j.meatsci. 2013.08.017

92. Gorman I, Balnave D. Effects of Dietary Mineral Supplementation on the Performance and Mineral Retentions of Broilers at High Ambient Temperatures. Br Poult Sci (1994) 35:563-72. doi: 10.1080/00071669408417721

93. Siegel HS. Stress Strains and Resistance. Br Poult Sci (1995) 36:3-22. doi: 10.1080/00071669508417748

94. Sahin K, Kucuk O. Zinc Supplementation Alleviates Heat Stress in Laying Japanese Quail. J Nutr (2003) 133:2808-11. doi: 10.1210/jc.2003-030380

95. Yang Y, Meng F, Wang P, Jiang Y, Yin Q, Chang J, et al. Effect of Organic and Inorganic Selenium Supplementation on Growth Performance, Meat Quality and Antioxidant Property of Broilers. Am J Bot (2012) 11:3031-6.

96. Zhang Z, Jia G, Zuo J, Zhang Y, Lei J, Ren L, et al. Effects of Constant and Cyclic Heat Stress on Muscle Metabolism and Meat Quality of Broiler Breast Fillet and Thigh Meat. Poult Sci (2012) 91:2931-7. doi: 10.3382/ps.2012-02255

97. Smith GC, Belk KE, Sofos JN, Tatum JD, Williams SN. Economic Implications of Improved Color Stability in Beef. Antioxidants Muscle Foods Nutr Strategies to Improve Qual (2000) 2000:397-426.

98. Khan AZ, Kumbhar S, Liu Y, Hamid M, Pan C, Nido SA, et al. Dietary Supplementation of Selenium-Enriched Probiotics Enhances Meat Quality of Broiler Chickens (Gallus Gallus Domesticus) Raised Under High Ambient Temperature. Biol Trace Elem Res (2018) 182:328-38. doi: 10.1007/s12011-017-1094-Z

99. National Research Council (U.S.). Nutrient Requirements of Dairy Cattle. Washington, D.C: National Academy of Sciences (2001).

100. Zimbelman RB, Rhoads RP, Rhoads ML, Duff GC, Baumgard LH, Collier RJ. A Re-Evaluation of the Impact of Temperature Humidity Index (THI) and Black Globe Temperature Humidity Index (BGHI) on Milk Production in High Producing Dairy Cows. Ieice Tech Rep Asn Ambient Intell Sensor Networks (2009), 158-68.

101. Bohmanova IJ, Misztal JBC. Temperature-Humidity Indices as Indicators of Milk Production Losses Due to Heat Stress. J Dairy Sci (2007) 90:1947-56. doi: 10.3168/jds.2006-513

102. West JW, Mullinix BG, Bernard JK. Effects of Hot, Humid Weather on Milk Temperature, Dry Matter Intake, and Milk Yield of Lactating Dairy Cows. J Dairy Sci (2003) 86:232-42. doi: 10.3168/jds.S0022-0302(03)73602-9

103. Bernabucci U, Basiricò L, Morera P, Dipasquale D, Vitali A, Piccioli CF, et al. Effect of Summer Season on Milk Protein Fractions in Holstein Cows. J Dairy Sci (2015) 98:1815-27. doi: 10.3168/jds.2014-8788

104. Hill DL, Wall E. Dairy Cattle in a Temperate Climate: The Effects of Weather on Milk Yield and Composition Depend on Management. Animal (2015) 9:138-49. doi: 10.1017/S1751731114002456

105. Rhoads ML, Rhoads RP, VanBaale MJ, Collier RJ, Sanders SR, Weber WJ, et al. Effects of Heat Stress and Plane of Nutrition on Lactating Holstein Cows: I. Production, Metabolism, and Aspects of Circulating Somatotropin. J Dairy Sci (2009) 92:1986-97. doi: 10.3168/jds.2008-1641

106. Adin G, Gelman A, Solomon R, Flamenbaum I, Nikbachat M, Yosef E. Effects of Cooling Dry Cows Under Heat Load Conditions on Mammary Gland Enzymatic Activity, Intake of Food and Water, and Performance During the Dry Period and After Parturition. Livest Sci (2009) 124:189-95. doi: 10.1016/j.livsci.2009.01.014

107. Heck JM, van Valenberg HJ, Dijkstra J, van Hooijdonk AC. Seasonal Variation in the Dutch Bovine Raw Milk Composition. J Dairy Sci (2009) 92:4745-55. doi: 10.3168/jds.2009-2146

108. Kadzere CT, Murphy MR, Silanikove N, Maltz E. Heat Stress in Lactating Dairy Cows: A Review. Livest Prod Sci (2002) 77:59-91. doi: 10.1016/S03016226(01)00330-X

109. Fabris TF, Laporta J, Corra FN, Torres YM, Kirk DJ, McLean DJ, et al. Effect of Nutritional Immunomodulation and Heat Stress During the Dry Period on Subsequent Performance of Cows. J Dairy Sci (2017) 100:6733-42. doi: $10.3168 /$ jds.2016-12313

110. Fabris TF, Laporta J, Skibiel AL. Effect of Heat Stress During Early, Late, and Entire Dry Period on Dairy Cattle. J Dairy Sci (2019) 102:5647-56. doi: $10.3168 /$ jds.2018-15721

111. Salman S, Dinse D, Khol-Parisini A, Schafft H, Lahrssen-Wiederholt M, Schreiner M, et al. Colostrum and Milk Selenium, Antioxidative Capacity and Immune Status of Dairy Cows Fed Sodium Selenite or Selenium Yeast. Arch Anim Nutr (2013) 67:48-61. doi: 10.1080/1745039X.2012.755327 
112. Zhang B, Guo Y, Yan S, Guo X, Zhao Y, Shi B. The Protective Effect of Selenium on the Lipopolysaccharide-Induced Oxidative Stress and Depressed Gene Expression Related to Milk Protein Synthesis in Bovine Mammary Epithelial Cells. Biol Trace Elem Res (2020) 197:141-8. doi: 10.1007/s12011-019-01961-7

113. Gong J, Ni L, Wang D, Shi B, Yan S. Effect of Dietary Organic Selenium on Milk Selenium Concentration and Antioxidant and Immune Status in Mid Lactation Dairy Cows. Livest Sci (2014) 170:84-90. doi: 10.1016/ j.livsci.2014.10.003

114. Bagath M, Krishnan G, Devaraj C, Rashamol VP, Pragna P, Lees AM, et al. The Impact of Heat Stress on the Immune System in Dairy Cattle: A Review. Res Vet Sci (2019) 126:94-102. doi: 10.1016/j.rvsc

115. Ju XH, Xu HJ, Yong YH, An L, Jiao PR, Liao M. Heat Stress Up Regulation of Toll-Like Receptors 2/4 and Acute Inflammatory Cytokines in Peripheral Blood Mononuclear Cell (PBMC) of Bama Miniature Pigs: An In Vivo and In Vitro Study. Anim (2014) 8:1462-8. doi: 10.1017/S1751731114001268

116. Jin Y, Hu Y, Han D, Wang M. Chronic Heat Stress Weakened the Innate Immunity and Increased the Virulence of Highly Pathogenic Avian Influenza Virus H5N1 in Mice. J BioMed Biotechnol (2011) 2011:36784656. doi: 10.1155/2011/367846

117. Mulhern SA, Taylor LE, Magruder LE, Vessey AR. Deficient Levels of Dietary Selenium Suppresses the Antibody Response in First and Second Generation Mice. Nutr Res (1985) 5:201-10. doi: 10.1016/S0271-5317(85) 80036-1

118. Meeker HC, Eskew ML, Sheuchenzuber W, Scholz RW, Zarkower A. Antioxidant Effects on Cell-Mediated Immunity. J Leukoc Biol (1985) 38:451-8. doi: 10.3109/03630268508997022

119. Bainbridge DR. Use of (75Se) L-Selenomethionine as a Label for Lymphoid Cells. Immunoly (1976) 30:135-44

120. Beck MA. Selenium and Vitamin E Status: Impact on Viral Pathogenicity. J Nutr (2007) 137:1338-40. doi: 10.1093/jn

121. Hoffmann PR, Jourdan-Le Saux C, Hoffmann FW, Chang PS, Bollt O, He Q, et al. A Role for Dietary Selenium and Selenoproteins in Allergic Airway Inflammation. J Immunol (2007) 179:3258-67. doi: 10.4049/jimmunol. 179.5.3258

122. Pavlick KP, Laroux FS, Fuseler J, Wolf RE, Gray L, Hoffman J, et al. Role of Reactive Metabolites of Oxygen and Nitrogen in Inflammatory Bowel Disease. Free Radic Biol Med (2002) 33:311-22. doi: 10.1016/S0891-5849 (02)00853-5

123. Drew JE, Farquharson AJ, Arthur JR, Morrice PC, Duthie GG. Novel Sites of Cytosolic Glutathione Peroxidase Expression in Colon. FEBS Lett (2005) 579:6135-9. doi: 10.1016/j.febslet.2005.09.085

124. Lu J, Holmgren A. Selenoproteins. J Biol Chem (2009) 284:723-7. doi: $10.1074 /$ jbc.R800045200

125. Furness JB, Rivera LR, Cho HJ, Bravo DM, Callaghan B. The Gut as a Sensory Organ. Nat Rev Gastroenterol Hepatol (2013) 10:729-40. doi: 10.1038/nrgastro.2013.180

126. Collin A, Lebreton Y, Fillaut M, Vincent A, Thomas HP. Effects of Exposure to High Temperature and Feeding Level on Regional Blood Flow and Oxidative Capacity of Tissues in Piglets. Exp Physiol (2001) 86:83-91. doi: $10.1113 /$ eph8602102

127. Lambert GP. Stress-Induced Gastrointestinal Barrier Dysfunction and its Inflammatory Effects. J Anim Sci (2009) 87:E101-8. doi: 10.2527/jas.20081339

128. Lambert GP, Gisolfi CV, Berg DJ, Moseley PL, Oberley LW, Kregel KC. Selected Contribution: Hyperthermia-Induced Intestinal Permeability and the Role of Oxidative and Nitrosative Stress. J Appl Physiol (2002) 92:175061. doi: 10.1152/japplphysiol.00787.2001

129. Zuhl M, Schneider S, Lanphere K, Conn C, Dokladny K, Moseley P. Exercise Regulation of Intestinal Tight Junction Proteins. Br J Sports Med (2014) 48:980-6. doi: 10.1136/bjsports-2012-091585

130. Marchiando AM, Graham WV, Turner JR. Epithelial Barriers in Homeostasis and Disease. Annu Rev Pathol (2010) 5:119-44. doi: 10.1146/ annurev.pathol.4.110807.092135

131. Chu F, Esworthy RS, Doroshow JH. Role of Se-Dependent Glutathione Peroxidases in Gastrointestinal Inflammation and Cancer. Free Radic Biol Med (2004) 36:1481-95. doi: 10.1016/j.freeradbiomed.2004.04.010
132. Maseko T, Dunshea FR, Howell K, Cho HJ, Rivera LR, Furness JB, et al. Selenium-Enriched Agaricus Bisporus Mushroom Protects Against Increase in Gut Permeability Ex Vivo and Up-Regulates Glutathione Peroxidase 1 and 2 in Hyperthermally-Induced Oxidative Stress in Rats. Nutrients (2014) 6:2478-92. doi: 10.3390/nu6062478

133. Liu F, Cottrell JJ, Furness JB, Rivera LR, Kelly FW, Wijesiriwardana U, et al. Selenium and Vitamin E Together Improve Intestinal Epithelial Barrier Function and Alleviate Oxidative Stress in Heat-Stressed Pigs. Exp Physiol (2016) 101:801-10. doi: 10.1113/EP085746

134. He Y, Liu Y, Tang J, Jia G, Liu G, Tian G, et al. Selenium Exerts Protective Effects Against Heat Stress-Induced Barrier Disruption and Inflammation Response in Jejunum of Growing Pigs. J Sci Food Agric (2021) 102:496-504. doi: $10.1002 /$ jsfa.11377

135. Hall D, Xu L, Drake V, Oberley L, Oberley T, Moseley P, et al. Aging Reduces Adaptive Capacity and Stress Protein Expression in the Liver After Heat Stress. J Appl Physiol (2000) 89:749-59. doi: 10.1055/s-2000-3839

136. Bhusari S, Hearne LB, Spiers DE, Lamberson WR, Antoniou E. Transcriptional Profiling of Mouse Liver in Response to Chronic Heat Stress. J Therm Biol (2008) 33:157-67. doi: 10.1016/j.jtherbio.2008.01.001

137. Cui Y, Hao Y, Li J, Bao W, Li G, Gao Y, et al. Chronic Heat Stress Induces Immune Response, Oxidative Stress Response, and Apoptosis of Finishing Pig Liver: A Proteomic Approach. Int J Mol Sci (2016) 17:393-417. doi: 10.3390/ijms17050393

138. Zhang HJ, Xu L, Drake VJ, Xie L, Oberley LW, Kregel KC. Heat-Induced Liver Injury in Old Rats is Associated With Exaggerated Oxidative Stress and Altered Transcription Factor Activation. FASEB J (2003) 17:2293-5. doi: 10.1096/fj.03-0139fje

139. Malyar RM, Naseri E, Li H, Ali I, Farid RA, Liu D, et al. Hepatoprotective Effects of Selenium-Enriched Probiotics Supplementation on Heat-Stressed Wistar Rat Through Anti-Inflammatory and Antioxidant Effects. Biol Trace Elem Res (2021) 199:3445-56. doi: 10.1007/s12011-020-02475-3

140. Khan AZ, Khan IU, Khan S, Afzal S, Hamid M, Tariq M, et al. SeleniumEnriched Probiotics Improve Hepatic Protection by Regulating ProInflammatory Cytokines and Antioxidant Capacity in Broilers Under Heat Stress Conditions. J Adv Vet Anim Res (2019) 6:355-61. doi: 10.5455/ javar.2019.f354

141. Liu SF, Malik AB. NF-Kappa B Activation as a Pathological Mechanism of Septic Shock and Inflammation. Am J Physiol Lung Cell Mol Physiol (2006) 290:L622-45. doi: 10.1152/ajplung.00477.2005

142. Liu Y, Liu Q, Ye G, Khan A, Liu J, Gan F, et al. Protective Effects of SeleniumEnriched Probiotics on Carbon Tetrachloride-Induced Liver Fibrosis in Rats. J Agric Food Chem (2014) 63:242-49. doi: 10.1021/jf5039184

143. Chen L, Pan DD, Zhou J, Jiang YZ. Protective Effect of Selenium-Enriched Lactobacillus on CCl4-Induced Liver Injury in Mice and its Possible Mechanisms. World J Gastroenterol: WJG (2005) 11:5795-800. doi: 10.1186/1471-230X-5-32

144. Gan F, Ren F, Chen X, Lv C, Pan C, Ye G, et al. Effects of Selenium-Enriched Probiotics on Heat Shock Protein mRNA Levels in Piglet Under Heat Stress Conditions. J Agric Food Chem (2013) 61:2385-91. doi: 10.1021/jf300249j

145. Gan F, Chen X, Liao SF, Lv C, Ren F, Ye G, et al. Selenium-Enriched Probiotics Improve Antioxidant Status, Immune Function, and Selenoprotein Gene Expression of Piglets Raised Under High Ambient Temperature. J Agric Food Chem (2014) 62:4502-8. doi: 10.1021/jf501065d

146. Krehl S, Loewinger M, Florian S, Kipp AP, Banning A, Wessjohann LA, et al. Glutathione Peroxidase-2 and Selenium Decreased Inflammation and Tumors in a Mouse Model of Inflammation-Associated Carcinogenesis Whereas Sulforaphane Effects Differed With Selenium Supply. Carcinogenesis (2012) 33:620-8. doi: 10.1093/carcin/bgr288

147. Huang Z, Aaron HR, Hoffmann PR. The Role of Selenium in Inflammation and Immunity: From Molecular Mechanisms to Therapeutic Opportunities. Antioxid Redox Sign (2012) 16:705-43. doi: 10.1089/ars.2011.4145

148. Gao B. Hepatoprotective and Anti-Inflammatory Cytokines in Alcoholic Liver Disease. J Gastroenterol Hepatol (2012) 27:89-93. doi: 10.1111/j.14401746.2011.07003.x

149. Ansar S. Effect of Selenium on the Levels of Cytokines and Trace Elements in Toxin-Mediated Oxidative Stress in Male Rats. Biol Trace Elem Res (2016) 169:129-33. doi: 10.1007/s12011-015-0403-7 
150. Tsuji PA, Carlson BA, Anderson CB, Seifried HE, Hatfield DL, Howard MT. Dietary Selenium Levels Affect Selenoprotein Expression and Support the Interferon- $\gamma$ and IL-6 Immune Response Pathways in Mice. Nutrients (2015) 7:6529-49. doi: 10.3390/nu7085297

151. Kuttappan VA, Manangi M, Bekker M, Chen J, Vazquez-Anon M. Nutritional Intervention Strategies Using Dietary Antioxidants and Organic Trace Minerals to Reduce the Incidence of Wooden Breast and Other Carcass Quality Defects in Broiler Birds. Front Physiol (2021) 12:663409. doi: 10.3389/fphys.2021.663409

152. Yang HH, Hou CC, Lin MT, Chang CP. Attenuating Heat-Induced Acute Lung Inflammation and Injury by Dextromethorphan in Rats. Am J Respir Cell Mol Biol (2012) 46:407-13. doi: 10.1165/rcmb.2011-0226OC

153. Yin Y, Guo J, Liu Z, Xu S, Zheng S. Selenium Deficiency Aggravates Heat Stress Pneumonia in Chickens by Disrupting the M1/M2 Balance. Biol Trace Elem Res (2021). doi: 10.1007/s12011-021-02905-w

154. Mack L, Felver-Gant J, Dennis R, Cheng HW. Genetic Variations Alter Production and Behavioral Responses Following Heat Stress in 2 Strains of Laying Hens. Poult Sci (2013) 92:285-94. doi: 10.3382/ps.2012-02589

155. Cebra CK, Heidel JR, Crisman RO, Stang BV. The Relationship Between Endogenous Cortisol, Blood Micronutrients, and Neutrophil Function in Postparturient Holstein Cows. J Vet Intern Med (2003) 17:902-7. doi: 10.1111/ j.1939-1676.2003.tb02531.x

156. Zhang Y, Liu Q, Yin H, Li S. Cadmium Exposure Induces Pyroptosis of Lymphocytes in Carp Pronephros and Spleens by Activating NLRP3. Ecotoxicol Environ Saf (2020) 202:110903-14. doi: 10.1016/j.ecoenv. 2020.110903

157. Chen MH, Li XJ, Shi QX, Zhang ZW, Xu SW. Hydrogen Sulfide Exposure Triggers Chicken Trachea Inflammatory Injury Through Oxidative StressMediated FOS/IL8 Signaling. J Hazard Mater (2019) 368:243-54. doi: 10.1016/j.jhazmat.2019.01.054

158. Koch F, Thom U, Albrecht E, Weikard R, Nolte W, Kuhla B, et al. Heat Stress Directly Impairs Gut Integrity and Recruits Distinct Immune Cell Populations Into the Bovine Intestine. Proc Natl Acad Sci U S A (2019) 116:10333-8. doi: 10.1073/pnas.1820130116

159. Nawab A, An L, Wu J, Li GH, Liu WC, Zhao Y. Chicken Toll-Like Receptors and Their Significance in Immune Response and Disease Resistance. Int revf Immunol (2019) 38:284-306. doi: 10.1080/08830185.2019.1659258

160. Vidya MK, Kumar VG, Sejian V, et al. Toll-Like Receptors: Significance, Ligands, Signaling Pathways, and Functions in Mammals. Int revf Immunol (2018) 37:20-36. doi: 10.1080/08830185.2017.1380200

161. Cao L, Tang J, Li Q, Xu J, Jia G, Liu G. Expression of Selenoprotein Genes is Affected by Heat Stress in IPEC-J2 Cells. Biol Trace Elem Res (2016) 172:35460. doi: 10.1007/s12011-015-0604-0

162. da Silva IC, Ribeiro AM, Canal CW, Trevizan L, Macagnan M, Gonçalves TA, et al. The Impact of Organic and Inorganic Selenium on the Immune System of Growing Broilers Submitted to Immune Stimulation and Heat Stress. Rev Bras Ciec Avícola (2010) 12:247-54. doi: 10.1590/S1516635X2010000400005

163. Habibian M, Ghazi S, Moeini MM, Abdolmohammadi A. Effects of Dietary Selenium and Vitamin E on Immune Response and Biological Blood Parameters of Broilers Reared Under Thermoneutral or Heat Stress Conditions. Int J Biometeorol (2014) 58:741-52. doi: 10.1007/s00484-013-0654-y

164. Liao X, Lu L, Li S, Liu S, Zhang L, Wang G, et al. Effects of Selenium Source and Level on Growth Performance, Tissue Selenium Concentrations, Antioxidation, and Immune Functions of Heat-Stressed Broilers. Biol Trace Elem Res (2012) 150:158-65. doi: 10.1007/s12011-012-9517-3

165. Gross WB, Siegel HS. Evaluation of Heterophil/Lymphocyte Ratio as a Measure of Stress in Chickens. Avian Dis (1983) 27:972-9. doi: 10.2307/ 1590198

166. Harmon BG. Avian Heterophils and Inflammation and Disease Resistance. Poult Sci (1998) 77:972-7. doi: 10.1093/ps/77.7.972

167. Leng L, Bobcek R, Kuricova S, Boldizarova K, Gresakova L, Sevcikova Z, et al. Comparative Metabolic and Immune Responses of Chickens Fed Diets Containing Inorganic Selenium and Sel-PlexTM Organic Selenium. Nottingham: Nottingham University Press (2003).

168. Abd El-Hack ME, Mahrose K, Arif M, Chaudhry MT, Saadeldin IM, Saeed $\mathrm{M}$, et al. Alleviating the Environmental Heat Burden on Laying Hens by Feeding on Diets Enriched With Certain Antioxidants (Vitamin E and
Selenium) Individually or Combined. Environ Sci Pollut Res Int (2017) 24:10708-17. doi: 10.1007/s11356-017-8690-5

169. Bordignon R, Volpato A, Glombowsky P, Souza CF, Silva A. Nutraceutical Effect of Vitamins and Minerals on Performance and Immune and Antioxidant Systems in Dairy Calves During the Nutritional Transition Period in Summer. J Therm Biol (2019) 84:451-9. doi: 10.1016/j.jtherbio. 2019.07.034

170. El-Sheikh AMH, Abdalla EA, Hanafy Maysa M. The Effect of Organic Selenium Supplementation on Productive and Physiological Performance in a Local Strain of Chicken. 2-Immune System and Some Physiological Aspects in Bandarah Chickens Affected by Organic Selenium. Egyptian Poult Sci (2010) 30:517-33.

171. Dukare S, Mir NA, Mandal AB, Dev K, Begum J, Tyagi PK, et al. Comparative Study on the Responses of Broiler Chicken to Hot and Humid Environment Supplemented With Different Dietary Levels and Sources of Selenium. J Therm Biol (2020) 88:102515-24. doi: 10.1016/ j.jtherbio.2020.102515

172. Habibian M, Sadeghi G, Ghazi S, Moeini MM. Selenium as a Feed Supplement for Heat-Stressed Poultry: A Review. Biol Trace Elem Res (2015) 165:183-93. doi: 10.1007/s12011-015-0275-x

173. Scheideler SE, Puthpongsiriporn U, Selly J. Vitamin E and Heat Stress in Layers. Zootec Int (2001) 3:40-5.

174. Xu D, Tian Y. Selenium and Polysaccharides of Atractylodes Macrocephala Koidz Play Different Roles in Improving the Immune Response Induced by Heat Stress in Chickens. Biol Trace Elem Res (2015) 168:235-41. doi: 10.1007/s12011-015-0351-2

175. Tang J, Cao L, Jia G, Liu G, Chen X, Tian G, et al. The Protective Effect of Selenium From Heat Stress-Induced Porcine Small Intestinal Epithelial Cell Line (IPEC-J2) Injury is Associated With Regulation Expression of Selenoproteins. Brit J Nutr (2019) 122:1081-90. doi: 10.1017/ S0007114519001910

176. Calabrese V, Cornelius C, Leso V, Trovato-Salinaro A, Ventimiglia B, Cavallaro M, et al. Oxidative Stress, Glutathione Status, Sirtuin and Cellular Stress Response in Type 2 Diabetes. Biochim Biophys Acta (2012) 1822:729-36. doi: 10.1016/j.bbadis.2011.12.003

177. Yang L, Tan GY, Fu YQ, Feng JH, Zhang MH. Effects of Acute Heat Stress and Subsequent Stress Removal on Function of Hepatic Mitochondrial Respiration, ROS Production and Lipid Peroxidation in Broiler Chickens. Comp Biochem Physiol C Toxicol Pharmacol (2010) 151:204-8. doi: 10.1016/ j.cbpc.2009.10.01

178. Imai H, Nakagawa Y. Biological Significance of Phospholipid Hydroperoxide Glutathione Peroxidase (PHGPx, GPx4) in Mammalian Cells. Free Radic Biol Med (2003) 34:145-69. doi: 10.1016/s0891-5849(02)01197-8

179. Martindale JL, Holbrook NJ. Cellular Response to Oxidative Stress: Signaling for Suicide and Survival. J Cell Physiol (2002) 192:1-15. doi: 10.1002/ jcp.10119

180. Green DR, Reed JC. Mitochondria and Apoptosis. Science (1998) 281:1309_ 12. doi: 10.1046/j.1432-1327.1998.2520001.x

181. Surai PF. Selenium in Poultry Nutrition 2. Reproduction, Egg and Meat Quality and Practical Applications. World's Poult Sci J (2002) 58:431-50. doi: 10.1079/WPS20020032

182. Young JF, Stagsted J, Jensen SK, Karlsson AH, Henckel P. Ascorbic Acid, Alpha-Tocopherol, and Oregano Supplements Reduce Stress-Induced Deterioration of Chicken Meat Quality. Poult Sci (2003) 82:1343-51. doi: $10.1093 / \mathrm{ps} / 82.8 .1343$

183. Guo Y, Zhang G, Yuan J, Nie W. Effects of Source and Level of Magnesium and Vitamin E on Prevention of Hepatic Peroxidation and Oxidative Deterioration of Broiler Meat. Anim Feed Sci Technol (2003) 107:143-50. doi: 10.1016/S0377-8401(03)00116-0

184. Tappel A. Tappel A. Oxidant Free Radical Initiated Chain Polymerization of Protein and Other Biomolecules and its Relationship to Diseases. Med Hypotheses (2004) 63:98-9. doi: 10.1016/j.mehy.2004.01.022

185. Nunes VA, Gozzo AJ, Cruz-Silva I, Juliano MA, Viel TA, Godinho RO, et al. Vitamin E Prevents Cell Death Induced by Mild Oxidative Stress in Chicken Skeletal Muscle Cells. Comp Biochem Physiol Part C Toxicol Pharmacol (2005) 141:225-40. doi: 10.1016/j.cca.2005.06.001

186. Sun LL, Gao ST, Wang K, Xu JC, Sanz-Fernandez MV, Baumgard LH, et al. Effects of Source on Bioavailability of Selenium, Antioxidant Status, and 
Performance in Lactating Dairy Cows During Oxidative Stress-Inducing Conditions. J Dairy Sci (2019) 102:311-9. doi: 10.3168/jds.2018-14974

187. Meng TT, Lin X, Xie CY, He JH, Xiang YK, Huang YQ, et al. Nanoselenium and Selenium Yeast Have Minimal Differences on Egg Production and Se Deposition in Laying Hens. Biol Trace Elem Res (2021) 199:2295-302. doi: 10.1007/s12011-020-02349-8

188. Meng T, Liu YL, Xie CY, Zhang B, Huang YQ, Zhang YW, et al. Effects of Different Selenium Sources on Laying Performance, Egg Selenium Concentration, and Antioxidant Capacity in Laying Hens. Biol Trace Elem Res (2019) 189:548-55. doi: 10.1007/s12011-018-1490-z

189. Galbraith ML, Vorachek WR, Estill CT, Whanger PD, Bobe G, Davis TZ, et al. Rumen Microorganisms Decrease Bioavailability of Inorganic Selenium Supplements. Biol Trace Elem Res (2016) 171:338-43. doi: 10.1007/s12011015-0560-8

190. Zou Y, Shao J, Li Y, Zhao FQ, Liu JX, Liu H. Protective Effects of Inorganic and Organic Selenium on Heat Stress in Bovine Mammary Epithelial Cells. Oxid Med Cell Longe (2019) 2019:1503478-1503488. doi: 10.1155/2019/ 1503478

191. Chauhan SS, Celi P, Leury BJ, Clarke IJ, Dunshea FR. Dietary Antioxidants at Supranutritional Doses Improve Oxidative Status and Reduce the Negative Effects of Heat Stress in Sheep. J Anim Sci (2014) 92:3364-74. doi: 10.2527/ jas.2014-7714

192. Kalmar B, Greensmith L. Induction of Heat Shock Proteins for Protection Against Oxidative Stress. Adv Drug Delivery Rev (2009) 61:310-8. doi: 10.1016/j.addr.2009.02.003

193. Kra B, Ama B, Bba B. The Diverse Functions of Small Heat Shock Proteins in the Proteostasis Network. J Mol Biol (2021) 14:167157-69. doi: 10.1016/ j.jmb.2021.167157

194. Salabi F, Boujarpoor M, Fayazi J, Salari S, Nazari M. Effects of Different Levels of Zinc on the Performance and Carcass Characteristics of Broiler Reared Under Heat Stress Condition. J Anim Vet Adv (2011) 10:1332-5. doi: 10.3923/javaa.2011.1332.1335

195. Geraert PA, Padilha JC, Guillaumin S. Metabolic and Endocrine Changes Induced by Chronic Heat Exposure in Broiler Chickens: Growth Performance, Body Composition and Energy Retention. Br J Nutr (1996) 75:195-204. doi: 10.1017/bjn19960124

196. Liu F, Cottrell JJ, Collins CL, Henman DJ, O'halloran KSB, Dunshea FR. Supplementation of Selenium, Vitamin E, Chromium and Betaine Above Recommended Levels Improves Lactating Performance of Sows Over Summer. Trop Anim Health Prod (2017) 49:1461-9. doi: 10.1007/s11250017-1348-y

197. Johnson AK, Marchant-Forde JN. "Welfare of Pigs in the Farrowing Environment”. In: The Welfare of Pigs. Dordrecht: Springer (2009).

198. Renaudeau D, Collin A, Yahav S, De Basilio V, Gourdine JL, Collier RJ. Adaptation to Hot Climate and Strategies to Alleviate Heat Stress in Livestock Production. Animal (2012) 6:707-28. doi: 10.1017/ S1751731111002448

199. Zhao S, Min L, Zheng N, Wang J. Effect of Heat Stress on Bacterial Composition and Metabolism in the Rumen of Lactating Dairy Cows. Anim (Basel) (2019) 9:925-35. doi: 10.3390/ani9110925

200. White HM, Richert BT, Schinckel AP, Burgess JR, Donkin SS. Latour MA Effects of Temperature Stress on Growth Performance and Bacon Quality in Grow-Finish Pigs Housed at Two Densities. J Anim Sci (2008) 86:1789-98. doi: $10.2527 /$ jas.2007-0801

201. Yu J, Yin P, Liu F, Cheng G, Guo K, Lu A, et al. Effect of Heat Stress on the Porcine Small Intestine: A Morphological and Gene Expression Study. Comp Biochem Physiol A Mol Integr Physiol (2010) 156:119-28. doi: 10.1016/ j.cbpa.2010.01.008

202. Kim KH, Hosseindoust A, Ingale SL, Lee SH, Noh HS, Choi YH, et al. Effects of Gestational Housing on Reproductive Performance and Behavior of Sows With Different Backfat Thickness. Asian Australas J Anim Sci (2016) 29:1428. doi: 10.5713/ajas.14.0973

203. Wegmann TG, Smithies D. A Simple Hemagglutination System Requiring Small Amount of Red Cells and Antibodies. Transfusion (2010) 6:67-73. doi: 10.1111/j.1537-2995.1966.tb04696.x

204. Snedecor GW, Cochran WG. Statistical Methods. Ames: Iowa State University Press (1989).
205. Fridivich I. The Biology of Oxygen Radicals. Science (1978) 201:875-80. doi: $10.1126 /$ science. 210504

206. Safdari-Rostamabad M, Hosseini-Vashan SJ, Perai AH, Sarir H. Nanoselenium Supplementation of Heat-Stressed Broilers: Effects on Performance, Carcass Characteristics, Blood Metabolites, Immune Response, Antioxidant Status, and Jejunal Morphology. Biol Trace Elem Res (2017) 178:105-16. doi: 10.1007/s12011-016-0899-5

207. Li JL, Li HX, Li S, Jiang ZH, Xu SW, Tang ZX. Selenoprotein W Gene Expression in the Gastrointestinal Tract of Chicken is Affected by Dietary Selenium. Biometals (2011) 24:291-9. doi: 10.1007/s10534-010-9395-0

208. Placha I, Takacova J, Ryzner M, Cobanova K, Laukova A, Strompfova V, et al. Effect of Thyme Essential Oil and Selenium on Intestine Integrity and Antioxidant Status of Broilers. Br Poult Sci (2014) 55:105-14. doi: 10.1080/ 00071668.2013.873772

209. Pearce SC, Mani V, Weber TE, Rhoads RP, Patience JF, Baumgard LH, et al. Heat Stress and Reduced Plane of Nutrition Decreases Intestinal Integrity and Function in Pigs. J Anim Sci (2013) 91:5183-93. doi: 10.2527/jas.20136759

210. Pearce SC, Mani V, Boddicker RL, Johnson J, Weber TE, Ross JW, et al. Heat Stress Reduces Barrier Function and Alters Intestinal Metabolism in Growing Pigs. J Anim Sci (2012) 90:257-9. doi: 10.2527/jas.52339

211. Ganesan S, Reynolds C, Hollinger K, Pearce SC, Gabler NK, Baumgard LH, et al. Twelve Hours of Heat Stress Induces Inflammatory Signaling in Porcine Skeletal Muscle. Am J Physiol - Reg I (2016) 310:R1288-96. doi: 10.1152/ ajpregu.00494.2015

212. Wei JY, Wang J, Liu W, Zhang KZ, Sun P. Short Communication: Effects of Different Selenium Supplements on Rumen Fermentation and Apparent Nutrient and Selenium Digestibility of Mid-Lactation Dairy Cows. J Dairy Sci (2019) 102:3131-5. doi: 10.3168/jds.2018-15455

213. Alimohamady R, Aliarabi H, Bahari A, Dezfoulian AH. Influence of Different Amounts and Sources of Selenium Supplementation on Performance, Some Blood Parameters, and Nutrient Digestibility in Lambs. Biol Trace Elem Res (2013) 154:45-54. doi: 10.1007/s12011-013-9698-4

214. Zhang ZD, Wang C, Du HS, Liu Q, Guo G, Huo WJ, et al. Effects of Sodium Selenite and Coated Sodium Selenite on Lactation Performance, Total Tract Nutrient Digestion and Rumen Fermentation in Holstein Dairy Cows. Animal (2020) 14:2091-9. doi: 10.1017/S1751731120000804

215. Hall DM, Buettner GR, Oberley LW, Xu L, Matthes RD, Gisolfi CV. Mechanisms of Circulatory and Intestinal Barrier Dysfunction During Whole Body Hyperthermia. Am J Physio-Heart Circ Physiol (2001) 280: H509-21. doi: 10.1046/j.1365-201x.2001.00790.x

216. Pearce SC, Mani V, Boddicker R, Johnson JS, Weber TE, Ross JW, et al. Heat Stress Reduces Intestinal Barrier Integrity and Favors Intestinal Glucose Transport in Growing Pigs. PLoS One (2013) 8:e70215-24. doi: 10.1371/ journal.pone.0070215

217. Shakeri M, Cottrell JJ, Wilkinson S, Zhao W, Le HH, McQuade R, et al. Dietary Betaine Improves Intestinal Barrier Function and Ameliorates the Impact of Heat Stress in Multiple Vital Organs as Measured by Evans Blue Dye in Broiler Chickens. Animals (2020) 10:38-52. doi: 10.3390/ ani10010038

218. Oskoueian E, Abdullah N, Idrus Z, Ebrahimi M, Goh YM, Shakeri M, et al. Palm Kernel Cake Extract Exerts Hepatoprotective Activity in Heat-Induced Oxidative Stress in Chicken Hepatocytes. BMC Complementary Altern Med (2014) 14:1-11. doi: 10.1186/1472-6882-14-368

219. Quinteiro-Filho W, Ribeiro A, Ferraz-de-Paula V, Pinheiro M, Sakai M, Sá L, et al. Heat Stress Impairs Performance Parameters, Induces Intestinal Injury, and Decreases Macrophage Activity in Broiler Chickens. Poult Sci (2010) 89:1905-14. doi: 10.3382/ps.2010-00812

220. Leser TD, Molbak L. Better Living Through Microbial Action: The Benefits of the Mammalian Gastrointestinal Microbiota on the Host. Environ Microbiol (2009) 11:2194-206. doi: 10.1111/j.1462-2920.2009.01941.x

221. Hooper LV, Littman DR, Macpherson AJ. Interactions Between the Microbiota and the Immune System. Science (2012) 336:1268-73. doi: $10.1126 /$ science. 1223490

222. Wang XJ, Feng JH, Zhang MH, Li XM, Ma DD, Chang SS. Effects of High Ambient Temperature on the Community Structure and Composition of Ileal Microbiome of Broilers. Poult Sci (2018) 97:2153-8. doi: 10.3382/ps/pey032 
223. He J, He Y, Pan D, Cao J, Sun Y, Zeng X. Associations of Gut Microbiota With Heat Stress-Induced Changes of Growth, Fat Deposition, Intestinal Morphology, and Antioxidant Capacity in Ducks. Front Microbiol (2019) 10:903. doi: $10.3389 /$ fmicb.2019.00903

224. Le Sciellour M, Zemb O, Hochu I, Riquet J, Gilbert H, Giorgi M, et al. Effect of Chronic and Acute Heat Challenges on Fecal Microbiota Composition, Production and Thermoregulation Traits in Growing Pigs. J Anim Sci (2019) 97:3845-558. doi: 10.1093/jas/skz222

225. Xing S, Wang X, Diao H, Zhang M, Zhou Y, Feng J. Changes in the Cecal Microbiota of Laying Hens During Heat Stress is Mainly Associated With Reduced Feed Intake. Poult Sci (2019) 98:5257-64. doi: 10.3382/ps/pez440

226. Zhu L, Liao R, Wu N, Zhu G, Yang C. Heat Stress Mediates Changes in Fecal Microbiome and Functional Pathways of Laying Hens. Appl Microbiol Biotechnol (2019) 103:461-72. doi: 10.1007/s00253-018-9465-8

227. Xiong Y, Yi H, Wu Q, Jiang Z, Wang L. Effects of Acute Heat Stress on Intestinal Microbiota in Grow-Finishing Pigs, and Associations With Feed Intake and Serum Profile. J Appl Microbiol (2020) 128:840-52. doi: 10.1111/ jam. 14504

228. Shi D, Bai L, Qu Q, Zhou S, Yang M, Guo S, et al. Impact of Gut Microbiota Structure in Heat-Stressed Broilers. Poult Sci (2019) 98:2405-13. doi: $10.3382 / \mathrm{ps} / \mathrm{pez026}$

229. Qu Q, Li H, Bai L, Zhang S, Sun J, Lv W, et al. Effects of Heat Stress on Gut Microbiome in Rats. Indian J Microbiol (2021) 61:338-47. doi: 10.1007/ s12088-021-00948-0

230. Mozes S, Bujnáková D, Sefcíková Z, Kmet V. Developmental Changes of Gut Microflora and Enzyme Activity in Rat Pups Exposed to Fat-Rich Diet. Obes (Silver Spring) (2008) 16:2610-5. doi: 10.1038/oby.2008.435

231. Cotillard A, Kennedy SP, Kong LC, Prifti E, Pons N, Le Chatelier E, et al. Dietary Intervention Impact on Gut Microbial Gene Richness. Nature (2013) 500:585-8. doi: 10.1038/nature12480

232. Zhai Q, Cen S, Li P, Tian F, Zhao J, Zhang H, et al. Effects of Dietary Selenium Supplementation on Intestinal Barrier and Immune Responses Associated With its Modulation of Gut Microbiota. Environ Sci Technol Lett (2018) 5:724-30. doi: 10.1021/acs.estlett.8b00563

233. Katoh K. MAFFT: A Novel Method for Rapid Multiple Sequence Alignment Based on Fast Fourier Transform. Nucleic Acids Res (2002) 30:3059-66. doi: 10.1093/nar/gkf436

234. Hector V, Bo Z, Yi M, Dai X, Wen Z, Yang G, et al. Effects of Se-Chitosan on the Growth Performance and Intestinal Health of the Loach Paramisgurnus Dabryanus (Sauvage). Aquaculture (2019) 498:263-70. doi: 10.1016/ j.aquaculture.2018.08.067

235. Gr A, Min YB, Kl A, Yang HA, Yu WC, Xx A, et al. Seleno-Lentinan Prevents Chronic Pancreatitis Development and Modulates Gut Microbiota in Mice. J Funct Foods (2016) 22:177-88. doi: 10.1016/j.jff.2016.01.035

236. Lv CH, Wang T, Regmi N, Chen X, Huang K, Liao SF. Effects of Dietary Supplementation of Selenium-Enriched Probiotics on Production Performance and Intestinal Microbiota of Weanling Piglets Raised Under High Ambient Temperature. J Anim Physiol Anim Nutr (Berl) (2015) 99:1161-71. doi: 10.1111/jpn.12326

237. Cui X, Wang Z, Tan Y, Chang S, Zheng H, Wang H, et al. Selenium Yeast Dietary Supplement Affects Rumen Bacterial Population Dynamics and Fermentation Parameters of Tibetan Sheep (Ovis Aries) in Alpine Meadow. Front Microbiol (2021) 12:663945. doi: 10.3389/fmicb.2021.663945

238. Collier RJ, Collier JL, Rhoads RP, Ba Umgard LH. Invited Review: Genes Involved in the Bovine Heat Stress Response. J Dairy Sci (2008) 91:445-54. doi: $10.3168 /$ jds.2007-0540

239. Wang X. Regulatory Functions of Phospholipase D and Phosphatidic Acid in Plant Growth, Development, and Stress Responses. Plant Physiol (2005) 139:566-73. doi: 10.1104/pp.105.068809

240. Bargmann BO, Munnik T. The Role of Phospholipase D in Plant Stress Responses. Curr Opin Plant Biol (2006) 9:515-22. doi: 10.5650/ oleoscience.13.471

241. Balogh G, Maulucci G, Gombos I, Horva I, T€or€ok Z, Peter M, et al. Heat Stress Causes Spatially-Distinct Membrane Re-Modelling in K562 Leukemia Cells. PLoS One (2011) 6:e21182-94. doi: 10.1371/journal.pone.0021182

242. Rayman MP. The Importance of Selenium to Human Health. Lancet (2000) 356:233-41. doi: 10.1016/S0140-6736(00)02490-9
243. Duntas LH, Benvenga S. Selenium: An Element for Life. Endocrine (2015) 48:756-75. doi: 10.1007/s12020-014-0477-6

244. Kumar N, Krishnani KK, Gupta SK, Singh NP. Selenium Nanoparticles Enhanced Thermal Tolerance and Maintain Cellular Stress Protection of Pangasius Hypophthalmus Reared Under Lead and High Temperature. Respir Physiol Neurobiol (2017) 246:107-16. doi: 10.1016/j.resp.2017.09.006

245. Barszcz M, Skomiał J. The Development of the Small Intestine of PigletsChosen Aspects. J Anim Feed Sci (2011) 20:3-15. doi: 10.1080/00071668. 2011.571035

246. Tang J, Jiang Y, Tang Y, Chen B, Sun X, Su L, et al. Effects of Propofol on Damage of Rat Intestinal Epithelial Cells Induced by Heat Stress and Lipopolysaccharides. Braz J Med Biol Res (2013) 46:507-12. doi: 10.1590/ 1414-431X20132785

247. Gathiram P, Wells MT, Brock-Utne JG, Gaffin SL. Anti-Lipopolysaccharide Improves Survival in Primates Subjected to Heat Stroke. Circ Shock (1987) 23:157-64.

248. Gathiram P, Wells MT, Brock-Utne JG, Gaffin SL. Prophylactic Corticosteroid Increases Survival in Experimental Heat Stroke in Primates. Aviat Space Environ Med (1988) 59:352-5. doi: 10.1097/ 00002060-198804000-00012

249. Chadio SE, Kotsampasi BM, Menegatos JG, Zervas GP, Kalogiannis DG. Effect of Selenium Supplementation on Thyroid Hormone Levels and Selenoenzyme Activities in Growing Lambs. Biol Trace Elem Res (2006) 109:145-54. doi: 10.1385/BTER:109:2:145

250. Tang JY, Wang LQ, Jia G, Liu GM, Chen XL, Tian G, et al. The HydroxyAnalogue of Selenomethionine Alleviated Lipopolysaccharide-Induced Inflammatory Responses is Associated With Recover Expression of Several Selenoprotein Encoding Genes in the Spleens of Kunming Mice. RSC Adv (2019) 9:40462-70. doi: 10.1039/C9RA07260H

251. Furuse M, Sasaki H, Fujimoto K. A Single Gene Product, Claudin-1 or -2, Reconstitutes Tight Junction Strands and Recruits Occludin in Fibroblasts. J Cell Biol (1998) 143:391-401. doi: 10.2307/1618843

252. Fanning AS, Anderson JM. PDZ Domains: Fundamental Building Blocks in the Organization of Protein Complexes at the Plasma Membrane. J Clin Invest (1999) 103:767-72. doi: 10.1172/JCI6509

253. Itoh M, Furuse M, Morita K, Kubota K, Tsukita S. Direct Binding of Three Tight Junction-Associated MAGUKs, ZO-1, ZO-2, and ZO-3, With the COOH Termini of Claudins. J Cell Biol (1999) 147:1351-63. doi: 10.1083/jcb.147.6.1351

254. Balda MS, Whitney JA, Flores C. Functional Dissociation of Paracellular Permeability and Transepithelial Electrical Resistance and Disruption of the Apical-Basolateral Intramembrane Diffusion Barrier by Expression of a Mutant Tight Junction Membrane Protein. J Cell Biol (1996) 134:1031-49. doi: $10.1083 /$ jcb.134.4.1031

255. Banu GS, Kumar G, Murugesan AG. Ethanolic Leaves Extract of Trianthema Portulacastrum L. Ameliorates Aflatoxin B1 Induced Hepatic Damage in Rats. Ind J Clin Biochem (2009) 24:250-6. doi: 10.1007/s12291-009-0047-5

256. Heads RJ, Yellon DM, Latchman DS. Differential Cytoprotection Against Heat Stress or Hypoxia Following Expression of Specific Stress Protein Genes in Myogenic Cells. J Mol Cell Cardiol (1995) 27:1669-78. doi: 10.1016/S00222828(95)90722-X

257. Huo C, Xiao C, She R, Liu T, Tian J, Dong H, et al. Chronic Heat Stress Negatively Affects the Immune Functions of Both Spleens and Intestinal Mucosal System in Pigs Through the Inhibition of Apoptosis. Int J Mol Sci (2019) 136:103672-9. doi: 10.1016/j.micpath.2019.103672

258. Iwaki K, Chi SH, Dillmann WH, Mestril R. Induction of HSP70 in Cultured Rat Neonatal Cardiomyocytes by Hypoxia and Metabolic Stress. Circulation (1993) 87:2023-32. doi: 10.1161/01.CIR.87.6.2023

259. Mosser DD, Caron AW, Bourget L, Denis-Larose C, Massie B. Role of the Human Heat Shock Protein Hsp70 in Protection Against Stress-Induced Apoptosis. Mol Cell Biol (1997) 17:5317-27. doi: 10.1128/MCB.17.9.5317

260. Jäättelä $M$, Wissing $D$, Kokholm K. Hsp70 Exerts its Anti-Apoptotic Function Downstream of Caspase 3-Like Proteases. EMBO J (1998) 17:6124-34. doi: 10.1093/emboj/17.21.6124

261. Kayama M, Nakazawa T, Thanos A, Morizane Y, Murakami Y, Theodoropoulou S. Heat Shock Protein 70 (HSP70) is Critical for the Photoreceptor Stress Response After Retinal Detachment via Modulating Anti-Apoptotic. Akt kinase Am J Pathol (2011) 178:1080-91. doi: 10.1016/j.ajpath.2010.11.072 
262. Musch MW, Ciancio MJ, Sarge K, Chang EB. Induction of Heat Shock Protein 70 Protects Intestinal Epithelial IEC-18 Cells From Oxidant and Thermal Injury. Am J Physiol (1996) 270:429-36. doi: 10.1002/ ajpa.1330990203

263. Cui Y, Gu X. Proteomic Changes of the Porcine Small Intestine in Response to Chronic Heat Stress. J Mol Endocrinol (2015) 55:277-93. doi: 10.1530/ JME-15-0161

264. Hall DM, Baumgardner KR, Oberley TD, Gisolfi CV. Splanchnic Tissues Undergo Hypoxic Stress During Whole Body Hyperthermia. Am J Physiol Gastrointest Liver Physiol (1999) 276:G1195-203. doi: 10.1152/ajpgi.1999. 276.5.G1195

265. Oliver SR, Phillips NA, Novosad VL, Bakos MP, Talbert EE, Clanton TL. Hyperthermia Induces Injury to the Intestinal Mucosa in the Mouse: Evidence for an Oxidative Stress Mechanism. Am J Physiol Regul Integr Comp Physiol (2012) 302:R845-53. doi: 10.1152/ajpregu.00595.2011

266. Rao R. Oxidative Stress-Induced Disruption of Epithelial and Endothelial Tight Junctions. Front Biosci (2008) 13:7210-26. doi: 10.2741/3223

267. Mahmoud KZ, Edens FW. Influence of Organic Selenium on Hsp70 Response of Heat-Stressed and Enteropathogenic Escherichia ColiChallenged Broiler Chickens (Gallus Gallus). Comp Biochem Physiol C Toxicol Pharmacol (2005) 141:69-75. doi: 10.1016/j.cca.2005.05.005

268. Yavuz T, Delibas N, Yildirim B, Altuntas I, Candır O, Cora A, et al. Vascular Wall Damage in Rats Induced by Methidathion and Ameliorating Effect of Vitamins E and C. Arch Toxicol (2004) 78:655-9. doi: 10.1007/s00204-0040593-9

269. Feder ME, Hofmann GE. Heat-Shock Proteins, Molecular Chaperones, and the Stress Response: Evolutionary and Ecological Physiology. Annu Rev Physiol (1999) 61:243-82. doi: 10.1146/annurev.physiol.61.1.243

270. Guertin MJ, Petesch SJ, Zobeck KL, Min IM, Lis JT. Drosophila Heat Shock System as a General Model to Investigate Transcriptional Regulation. Cold Spring Harb Sym (2010) 75:1-9. doi: 10.1101/sqb.2010.75.039

271. Cedraz H, Gromboni JGG, Garcia AAPJ, Farias Filho RV, Souza TM, Oliveira ER, et al. Heat Stress Induces Expression of HSP Genes in Genetically Divergent Chickens. PLoS One (2017) 12:e0186083-e0186098. doi: 10.1371/journal.pone.0186083

272. Richter K, Haslbeck M, Buchner J. The Heat Shock Response: Life on the Verge of Death. Mol Cell (2010) 40:253-66. doi: 10.1016/j.molcel. 2010.10.006

273. Liu CP, Fu J, Xu FP, Wang XS, Li S. The Role of Heat Shock Proteins in Oxidative Stress Damage Induced by Se Deficiency in Chicken Livers. BioMetals (2015) 28:163-73. doi: 10.1007/s10534-014-9812-x

274. Zhao J, Xing H, Liu C, Zhang Z, Xu S. Effect of Selenium Deficiency on Nitric Oxide and Heat Shock Proteins in Chicken Erythrocytes. BiolTrace Elem Res (2016) 171:208-13. doi: 10.1007/s12011-015-0527-9

275. Calamari L, Petrera F, Abeni F, Bertin G. Metabolic and Hematological Profiles in Heat Stressed Lactating Dairy Cows Fed Diets Supplemented With Different Selenium Sources and Doses. Livest Sci (2011) 142:128-37. doi: 10.1016/j.livsci.2011.07.005

276. Ma Q. Role of Nrf2 in Oxidative Stress and Toxicity. Annu Rev Pharmacol (2013) 53:401-26. doi: 10.1146/annurev-pharmtox-011112-140320

277. Lu MC, Ji JA, Jiang ZY, You QD. The Keap1-Nrf2-ARE Pathway as a Potential Preventive and Therapeutic Target: An Update. Med Res Rev (2016) 36:924-63. doi: 10.1002/med.21396

278. Hara S, Shoji Y, Sakurai A, Yuasa K, Himeno S, Imura N. Effects of Selenium Deficiency on Expression of Selenoproteins in Bovine Arterial Endothelial Cells. Biol Pharm Bull (2001) 24:754-9. doi: 10.1248/bpb.24.754

279. Li GC, Mivechi NF, Weitzel G. Heat Shock Proteins, Thermotolerance, and Their Relevance to Clinical Hyperthermia. Int J Hyperthermia (1995) 11:459-88. doi: 10.3109/02656739509022483

280. Liu Y, He A, Tang J, Shah AM, Jia G, Liu G, et al. Selenium Alleviates the Negative Effect of Heat Stress on Myogenic Differentiation of C2C12 Cells With the Response of Selenogenome. J Therm Biol (2021) 97:102874-82. doi: 10.1016/j.jtherbio.2021.102874

281. Tang JY, He AH, Yan H. Damage to the Myogenic Differentiation of C2C12 Cells by Heat Stress is Associated With Up-Regulation of Several Selenoproteins. Sci Rep (2018) 8:10601-10. doi: 10.1038/s41598-01829012-6
282. Gromer S, Eubel JK, Lee BL. Human Selenoproteins at a Glance. Cell Mol Life Sci (2005) 62:2414-37. doi: 10.1007/s00018-005-5143-y

283. Munira B, Diego B, Balazs G. Human Type 3 Iodothyronine Selenodeiodinase is Located in the Plasma Membrane and Undergoes Rapid Internalization to Endosomes. J Biol Chem (2003) 278:1206-11. doi: $10.1074 /$ jbc.M210266200

284. Baqui MM, Gereben B, Harney JW, Larsen PR, Bianco AC. Distinct Subcellular Localization of Transiently Expressed Types 1 and 2 Iodothyronine Deiodinases as Determined by Immunofluorescence Confocal Microscopy. Endocrinology (2000) 141:4309-12. doi: 10.1210/ endo.141.11.7872

285. Shchedrina VA, Everley RA, Zhang Y, Gygi SP, Hatfield DL, Gladyshev VN. Selenoprotein K Binds Multiprotein Complexes and is Involved in the Regulation of Endoplasmic Reticulum Homeostasis. J Biol Chem (2011) 286:42937-48. doi: 10.1074/jbc.M111.310920

286. Sengupta A, Carlson BA, Labunskyy VM, Gladyshev VN, Hatfield DL. Selenoprotein $\mathrm{T}$ Deficiency Alters Cell Adhesion and Elevates Selenoprotein W Expression in Murine Fibroblast Cells. Biochem Cell Biol (2009) 87:953-61. doi: 10.1139/o09-064

287. Labunskyy VM, Hatfield DL, Gladyshev VN. The Sep15 Protein Family: Roles in Disulfide Bond Formation and Quality Control in the Endoplasmic Reticulum. IUBMB Life (2007) 59:1-5. doi: 10.1080/15216540601126694

288. Barrett NW, Rowland K, Schmidt CJ, Lamont SJ, Rothschild MF, Ashwell $\mathrm{CM}$, et al. Effects of Acute and Chronic Heat Stress on the Performance, Egg Quality, Body Temperature, and Blood Gas Parameters of Laying Hens. Poult Sci (2019) 98:6684-92. doi: 10.3382/ps/pez541

289. Akbarinejad V, Gharagozlou F, Vojgani M. Temporal Effect of Maternal Heat Stress During Gestation on the Fertility and Anti-Mullerian Hormone Concentration of Offspring in Bovine. Theriogenology (2017) 99:69-78. doi: 10.1016/j.theriogenology.2017.05.018

290. Manabe N, Goto Y, Matsuda-Minehata F, Inoue N, Maeda A, Sakamaki K, et al. Regulation Mechanism of Selective Atresia in Porcine Follicles: Regulation of Granulosa Cell Apoptosis During Atresia. J Reprod Dev (2004) 50:493-514. doi: 10.1262/jrd.50.493

291. Hale BJ, Hager CL, Seibert JT, Selsby JT, Baumgard LH, Keating AF, et al. Heat Stress Induces Autophagy in Pig Ovaries During Follicular Development. Biol Reprod (2017) 97:426-37. doi: 10.1093/biolre/iox097

292. Wang Y, Yang C, Elsheikh N, Li C, Yang F, Wang G, et al. HO-1 Reduces Heat Stress-Induced Apoptosis in Bovine Granulosa Cells by Suppressing Oxidative Stress. Aging (2019) 11:5535-47. doi: 10.18632/aging.102136

293. Naseer Z, Ahmad E, Epikmen ET, Ucan U, Boyacioglu M, Ipek E, et al. Quercetin Supplemented Diet Improves Follicular Development, Oocyte Quality, and Reduces Ovarian Apoptosis in Rabbits During Summer Heat Stress. Theriogenology (2017) 96:136-41. doi: 10.1016/j.theriogenology. 2017.03.029

294. Walter P, Ron D. The Unfolded Protein Response: From Stress Pathway to Homeostatic Regulation. Science (2011) 334:1081-6. doi: 10.1126/ science. 1209038

295. Lin CL. Attenuation of Endoplasmic Reticulum Stress as a Treatment Strategy Against Ischemia/Reperfusion Injury. Neural Regener Res (2015) 10:1930-1. doi: 10.4103/1673-5374.169615

296. Gao L, Chen H, Li C, Xiao Y, Yang D, Zhang M, et al. ER Stress Activation Impairs the Expression of Circadian Clock and Clock-Controlled Genes in NIH3T3 Cells via an ATF4-Dependent Mechanism. Cell Signal (2019) 57:89-101. doi: 10.1016/j.cellsig.2019.01.008

297. Iurlaro R, Munoz-Pinedo C. Cell Death Induced by Endoplasmic Reticulum Stress. FEBS J (2016) 283:2640-52. doi: 10.1111/febs.13598

298. Lin P, Yang Y, Li X, Chen F, Cui C, Hu L, et al. Endoplasmic Reticulum Stress is Involved in Granulosa Cell Apoptosis During Follicular Atresia in Goat Ovaries. Mol Reprod Dev (2012) 79:423-32. doi: 10.1002/mrd.22045

299. Xiong Y, Yin Q, Jin E, Chen H, He S. Selenium Attenuates Chronic Heat Stress-Induced Apoptosis via the Inhibition of Endoplasmic Reticulum Stress in Mouse Granulosa Cells. Molecules (2020) 25:557-74. doi: 10.3390/molecules 25030557

300. Abdulrashid M, Juniper DT. Effect of Dietary Protein, Selenium and Temperature Humidity Index on Reproductive Traits of Male Rabbits in a Tropical Environment. J Ani Prod Res (2016) 28:61-5. 
301. El-Desoky NI, Hashem NM, Elkomy A, Abo-elezz ZR. Physiological Response and Semen Quality of Rabbit Bucks Supplemented With Moringa Leaves Ethanolic Extract During Summer Season. Animal (2017) 11:1549-57. doi: 10.1017/S1751731117000088

302. Kehr S, Malinouski M, Finney L, Vogt S, Labunskyy VM, Kasaikina MV, et al. $\mathrm{X}$-Ray Fluorescence Microscopy Reveals the Role of Selenium in Spermatogenesis. J Mol Biol (2009) 389:808-18. doi: 10.1016/j.jmb.2009.04.024

303. Ahsan U, Kamran Z, Raza I, Ahmad S, Babar W, Riaz MH, et al. Role of Selenium in Male Reproduction-A Review. Anim Prod Sci (2014) 46:55-62. doi: 10.1016/j.anireprosci.2014.01.009

304. Bano I, Malhim M, Soomro SA, Kandhro S, Awais M, Baloch S, et al. Effect of Dietary Selenium Supplementation on Morphology and Antioxidant Status in Testes of Goat. J Basic Appl Sci (2018) 14:53-61. doi: 10.6000/1927-5129.2018.14.08

305. Qazi IH, Angel C, Yang H, Zoidis E, Pan B, Wu Z, et al. Role of Selenium and Selenoproteins in Male Reproductive Function: A Review of Past and Present Evidences. Antioxidants (2019) 8:268-304. doi: 10.3390/antiox8080268

306. Hosny, Nourhan S. Effects of Organic Selenium on the Physiological Response, Blood Metabolites, Redox Status, Semen Quality, and Fertility of Rabbit Bucks Kept Under Natural Heat Stress Conditions. Front Vet Sci (2020) 7:290. doi: 10.3389/fvets.2020.00290

307. Surai PF. Vitamin E in Avian Reproduction. Poult Avian Biol Rev (1999) 10:1-60. doi: 10.1016/S0301-6226(98)00158-4

308. Surai PF. Effect of Selenium and Vitamin E Content of the Maternal Diet on the Antioxidant System of the Yolk and the Developing Chick. Br Poult Sci (2000) 41:235-43. doi: 10.1080/713654909
309. Ebeid TA. Organic Selenium Enhances the Antioxidative Status and Quality of Cockerel Semen Under High Ambient Temperature. Br Poult Sci (2009) 50:641-7. doi: 10.1080/00071668.2012.722192

310. Ebeid TA. Vitamin E and Organic Selenium Enhances the Antioxidative Status and Quality of Chicken Semen Under High Ambient Temperature. Br Poult Sci (2012) 53:708-14. doi: 10.1080/00071668.2012.722192

Conflict of Interest: The authors declare that the research was conducted in the absence of any commercial or financial relationships that could be construed as a potential conflict of interest.

Publisher's Note: All claims expressed in this article are solely those of the authors and do not necessarily represent those of their affiliated organizations, or those of the publisher, the editors and the reviewers. Any product that may be evaluated in this article, or claim that may be made by its manufacturer, is not guaranteed or endorsed by the publisher.

Copyright $\odot 2022$ Zheng, Xie, Li, Wang, Wang, Cao and Yang. This is an open-access article distributed under the terms of the Creative Commons Attribution License (CC BY). The use, distribution or reproduction in other forums is permitted, provided the original author(s) and the copyright owner(s) are credited and that the original publication in this journal is cited, in accordance with accepted academic practice. No use, distribution or reproduction is permitted which does not comply with these terms. 